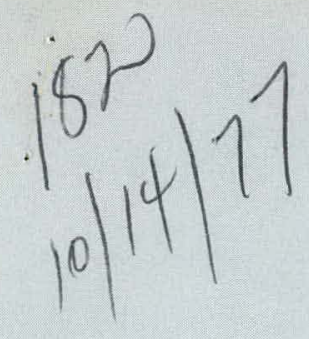

\title{
A LINEAR-INDUCTION-MOTOR SLIDE DRIVE
}

W. E. Barkman

\section{MASTER}

October 1977

OAK RIDGE Y-12 PLANT

OAK RIDGE, TENNESSEE

prepared for the U.S. ENERGY RESEARCH AND DEVELOPMENT ADMINISTRATION under U.S. GOVERNMENT Contract W-7405 eng 26 


\section{DISCLAIMER}

This report was prepared as an account of work sponsored by an agency of the United States Government. Neither the United States Government nor any agency Thereof, nor any of their employees, makes any warranty, express or implied, or assumes any legal liability or responsibility for the accuracy, completeness, or usefulness of any information, apparatus, product, or process disclosed, or represents that its use would not infringe privately owned rights. Reference herein to any specific commercial product, process, or service by trade name, trademark, manufacturer, or otherwise does not necessarily constitute or imply its endorsement, recommendation, or favoring by the United States Government or any agency thereof. The views and opinions of authors expressed herein do not necessarily state or reflect those of the United States Government or any agency thereof. 


\section{DISCLAIMER}

Portions of this document may be illegible in electronic image products. Images are produced from the best available original document. 
Reference to a company or product name does not imply approval or recommendation of the product by Union Carbide Corporation or the U.S. Energy Research and Development Administration to the exclusion of others that may meet specifications.

Printed in the United States of America. Available from National Technical Information Service

U.S. Department of Commerce

5285 Port Royal Road, Springfield, Virginia 22161

Price: Printed Copy $\$ 400$; Microfiche $\$ 3.00$

$$
4,50
$$

This report was prepared as an account of work sponsored by the United States Government. Neither the United States nor the Energy Research and Development Administration, nor any of their employees, nor any of their contractors, subcontractors, or their employees, makes any warranty, express or implied, or assumes any legal liability or responsibility for the accuracy, completeness or usefulness of any information, apparatus, product or process disclosed, or represents that its use would not infringe privately owned rights. 
Date of Issue: October 11, 1977

Distribution Category: UC-38

\title{
A LINEAR-INDUCTION-MOTOR SLIDE DRIVE
}

\author{
W. E. Barkman
}

Fabrication Systems Department

Y-12 Development Division

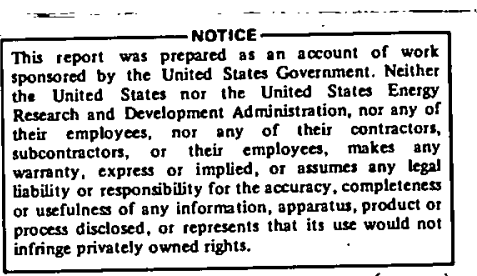

Oak Ridge Y-12 Plant

P. O. Box Y, Oak Ridge, Tennessee 37830

Prepared for the US Energy Research and Development Administration Under US Government Contract W-7405-eng-28 


\begin{abstract}
A linear-induction-motor drive system has been developed on a test bed that utilizes an air-bearing slide, laser interferometer feedback, and a microprocessor-based servo system. Static and dynamic positioning accuracies of $\pm 16 \mathrm{~nm}( \pm 0.6 \mu \mathrm{in})$ have been demonstrated.
\end{abstract}




\section{CONTENTS}

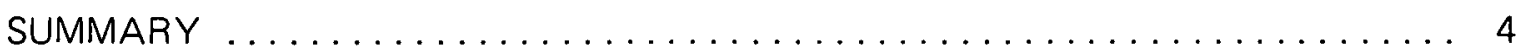

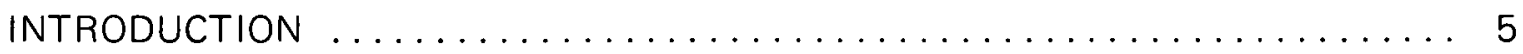

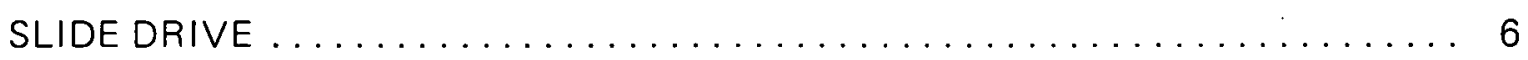

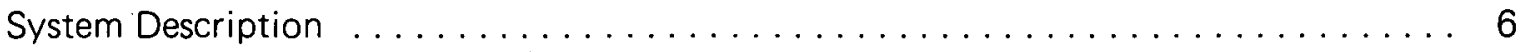

System Components .................................. 6

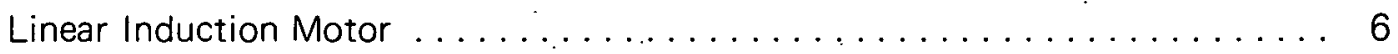

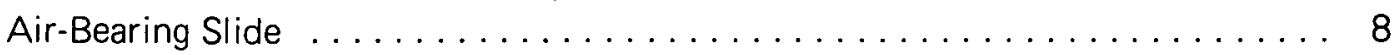

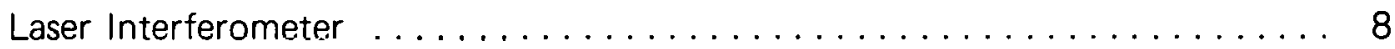

Microprocessor Hardware and Software $\ldots \ldots \ldots \ldots \ldots \ldots \ldots \ldots \ldots$

Servo System . . . . . . . . . . . . . . . . . . . . . . 10

Results .............................................. 11

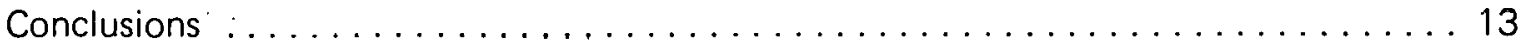

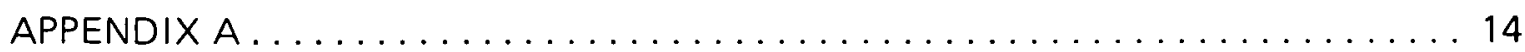

Force Characteristic .................................... 14

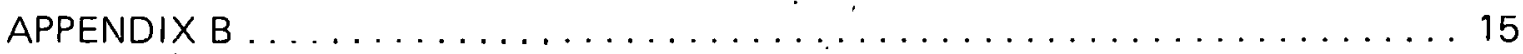

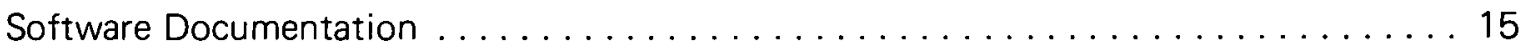

Laser Compensation ................................ 15

Initialization .................................... 15

Read Feedback Counts ................................ 18

Feedback Counts Conversion . . . . . . . . . . . . . . . . . 18

Negative Feedback Value Conversion . . . . . . . . . . . . . . . . 20

Feedback Value Storage . . . . . . . . . . . . . . . . . . . . . . . 20

Read Command Counts .............................. 20

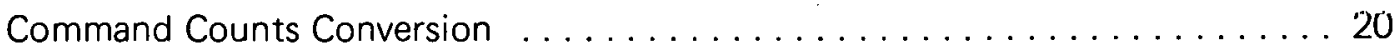

Positive Command Value Conversion ....................... 20

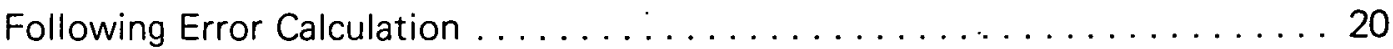

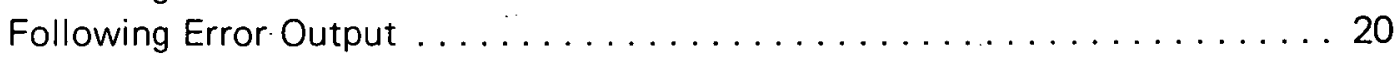

Algorithm Logic ................................. 25

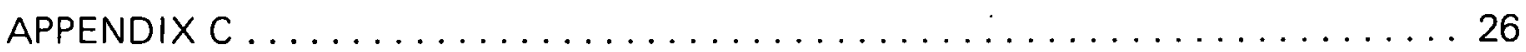

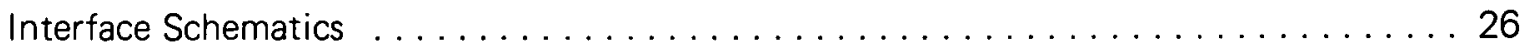




\section{SUMMARY}

A linear-induction-motor drive system has been developed which provides a slide motion that is smoother and more accurate than the conventional ball nut/lead screw drives. The system has been assembled on a test bed and utilizes an air-bearing slide, laser interferometer feedback, and a microprocessor-based servo system.

The system is programmed to accept 25.4-nm (1- $\mu$ in) commands and exhibits a static positioning ability of $\pm 16 \mathrm{~nm}( \pm 0.6 \mu \mathrm{in})$. The dynamic positioning accuracy is also $\pm 16 \mathrm{~nm}$ $( \pm 0.6 \mu \mathrm{in})$ at feedrates between 0.01 and $0.1 \mathrm{ipm}$. 


\section{INTRODUCTION}

The primary method used in the Oak Ridge $\mathrm{Y}-12$ Plant $(a)$ to position machine tool slides utilizes a rotary prime mover coupled to a ball nut/lead screw. Linear slide motion is obtained by attaching the ball nut to the machine slide and driving the lead screw through a gear box. Slide-position information is obtained from a feedback device, such as a resolver or encoder, which is coupled to the lead screw. Unfortunately, vibration and positioning uncertainties are introduced due to the drive and feedback gearing that adversely affect the part quality. In addition, this gearing requires routine maintenance and may be damaged extensively if a machine slide forcefully contacts a stationary member, or "wrecks".

In order to obtain a smooth, accurate, low-maintenance slide motion, a linear-inductionmotor drive system has been developed that utilizes an air-bearing slide, laser interferometer feedback, and a microprocessor-based servo system. The microprocessor has been programmed to accept position-command and position-feedback information and to generate the following error data. An analog servo system is used to generate the motor control signal.

(a) Operated by the Union Carbide Corporation's Nuclear Division for the US Energy Research and Development Administration. 


\section{SLIDE DRIVE}

\section{SYSTEM DESCRIPTION}

The linear-induction-motor test bed, shown in Figure 1, consists of an air-bearing slide mounted on a steel-topped concrete table, a linear motor, a laser interferometer, and a microprocessor-based control system. Figure 2 is a block diagram of the system. A detailed description of each of the basic system components follows.

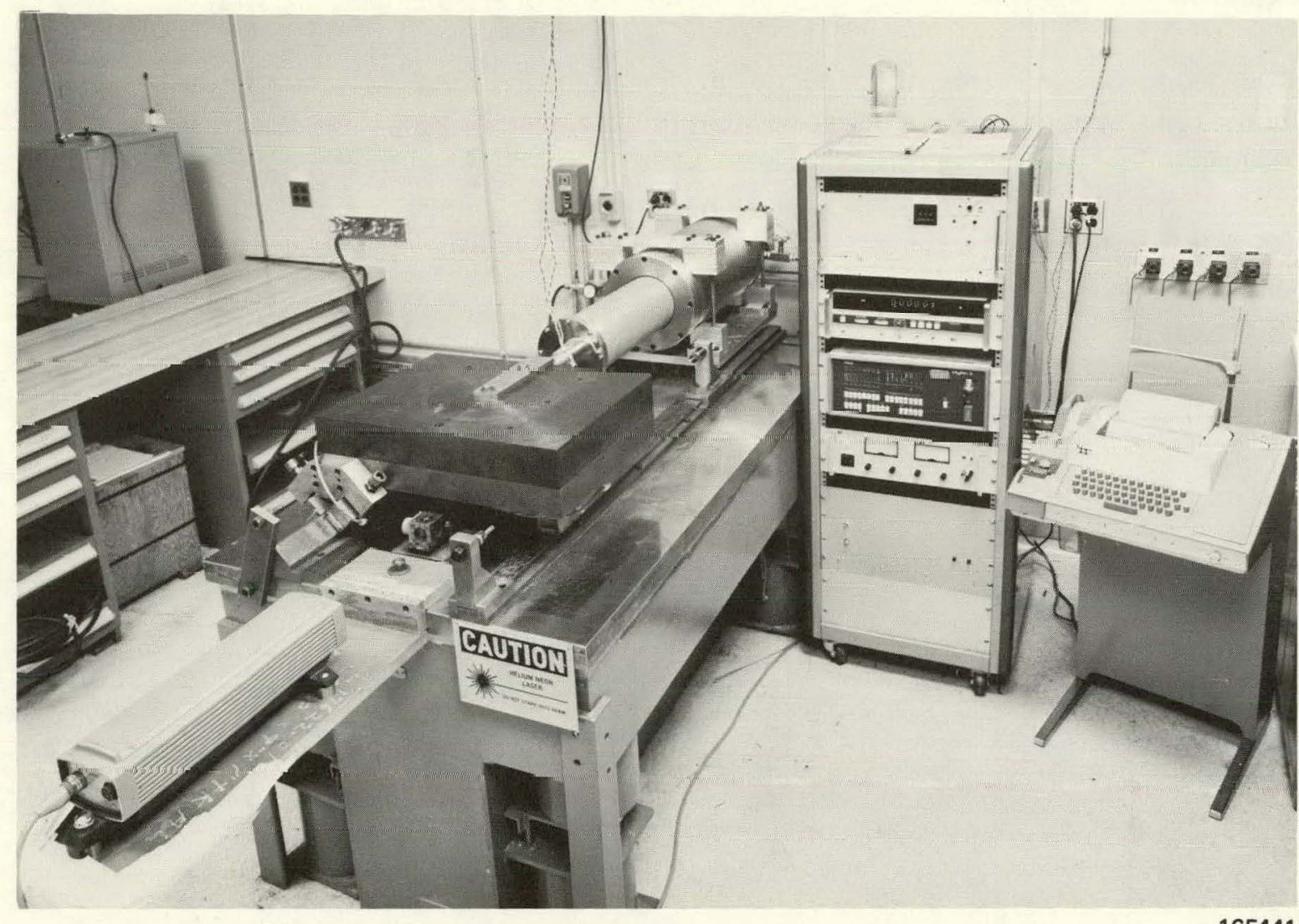

Figure 1. LINEAR-INDUCTION-MOTOR TEST BED.

\section{SYSTEM COMPONENTS}

\section{Linear Induction Motor}

The motor cross section is shown in Figure 3. The stator is $305 \mathrm{~mm}$ (12 in) in diameter by $660 \mathrm{~mm}$ (26 in) long, and encloses' a central pole piece. The exciting coil that generates the DC magnetic field for the stator is located near the forward end of the frame and is cooled by circulating water.

The motor moving member is attached to the air-bearing slide and undergoes an axial force that is a function of the electric current flowing through the control coil. The motor 


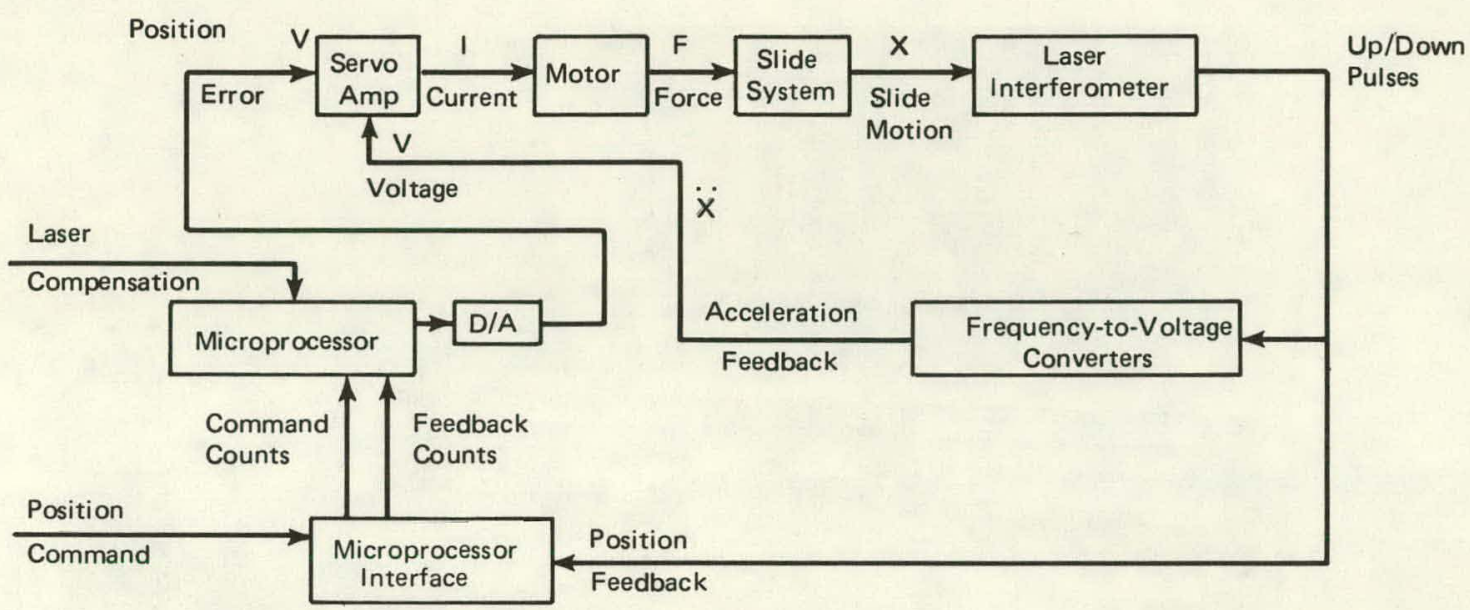

Figure 2. SYSTEM COMPONENTS.

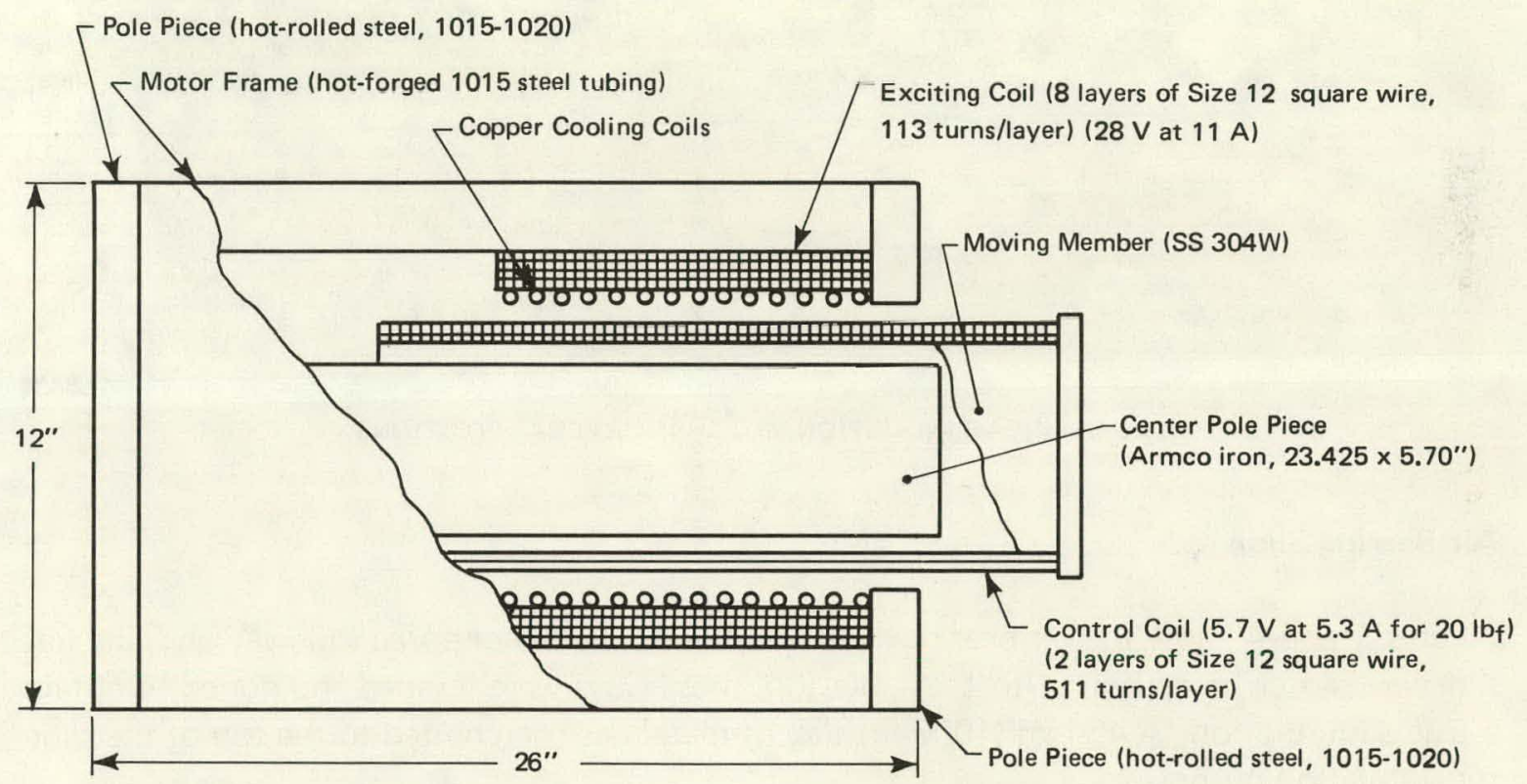

Figure 3. LINEAR INDUCTION MOTOR.

operation is analogous to a DC torque motor with the exception of the travel limit imposed by the moving member stroke. Figure 4 shows the slide in several positions.

The motor is designed to have a nominal force rating of $45 \mathrm{~N}(10 \mathrm{lb})$ with a maximum available force of $90 \mathrm{~N}(20 \mathrm{lbs})$. The maximum current required to develop the $90-\mathrm{N}(20-\mathrm{lb})$ force occurs when the moving member (and its control coil) is extended all the way out of the motor. At this point, the force generated is approximately equal to 3.76 times the control coil current (in amperes). A plot of the control coil position versus the force coefficient for small currents is included in Appendix A. For large currents, a significant magnetizing or demagnetizing of the exciting coil is produced. The worst case is when the control coil is retracted all the way into the motor and the control current is flowing to yield a force to move the coil outward. 


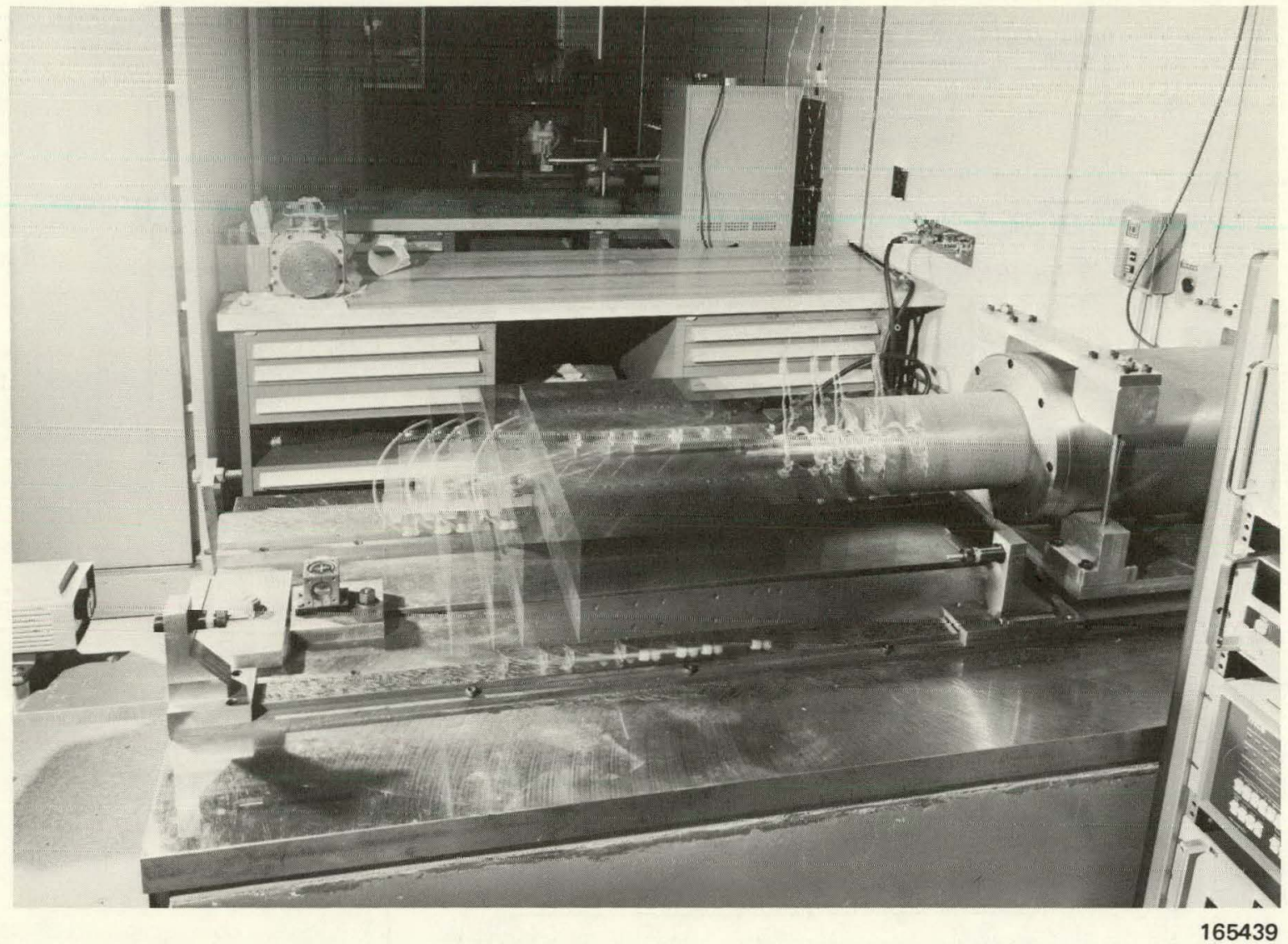

Figure 4. LINEAR INDUCTION MOTOR IN SEVERAL POSITIONS.

\section{Air-Bearing Slide}

Figures 1 and 4 show the air-bearing slide which is guided by one Vee slideway and one flat slideway. After being bolted to the table top, these ways were scraped and honed to obtain a true slide motion. A $454-\mathrm{kg}(1000-\mathrm{lb})$ slab of metal has been bolted to the top of the slide tor simulation purposes.

\section{Laser Interferometer}

The system position feedback device is a Hewlett-Packard laser interferometer. The remule interfernmeter is bolted to the table top and may be seen in Figures 1 and 4 . The remote reflector is attached to the slide. Position information is provided to the micruprocessor from the up/down pulse output of the laser interferometer display. A $10 \mathrm{X}$ resolution extender is used to obtain a pulse resolution of approximately $16 \mathrm{~nm}(0.6228 \mu \mathrm{in})$ per pulse.

The laser transducer has an accuracy of \pm 0.5 part per million and a maximum velocity of 72 inches per minute in the $10 \mathrm{X}$ mode. Thumbwheel switches on the laser display and microprocessor interface are provided for the correction of errors due to ambient temperature, pressure, and humidity. 


\section{Microprocessor Hardware and Software}

The slide control system is based on an Intel 8080 microprocessor. Figure 1 shows an Intellec 8 (which contains the 8080) mounted in the rack below the laser display. The Intellec 8 is being used for system development and will be replaced by a dedicated control processor when the system configuration is finalized.

The microprocessor reads the command and feedback information from two 8-bit up/down counters and converts this information into the system following error, as indicated in Figure 5. In addition, the processor reads a laser wavelength compensation value from a set of thumbwheel switches and uses these data to adjust the calculated following error for environmental changes. The value of a command pulse is $25.4 \mathrm{~nm}$ (1 $\mu \mathrm{in}$ ) while the resolution of the 1/4-wavelength feedback pulse is approximately $16 \mathrm{~nm}(0.6228 \mu \mathrm{in})$.(b) The schematic for the laser interface and the system control software is contained in Appendix B.

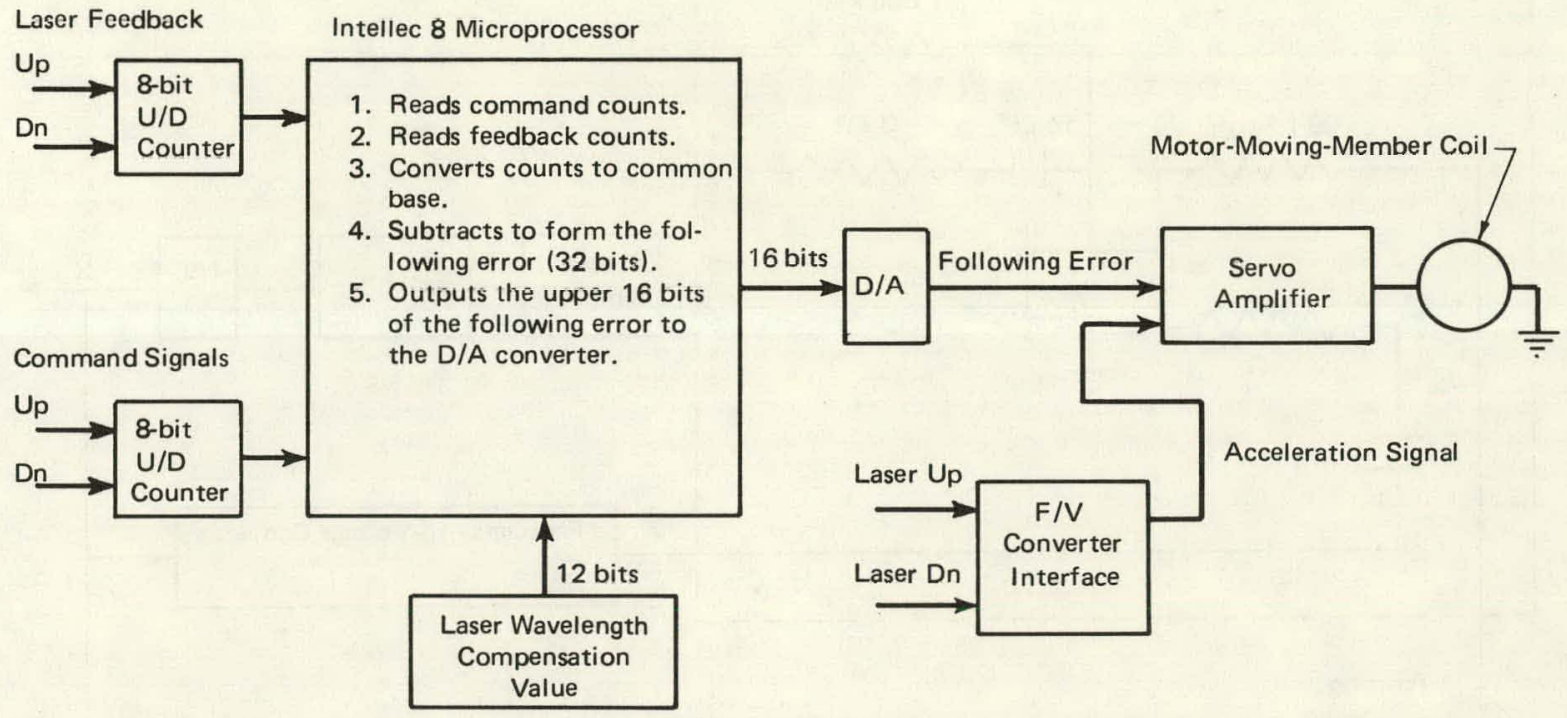

Figure 5. FUNCTIONS OF THE MICROPROCESSOR.

In order to generate the slide-drive signal, the microprocessor forms a 32-bit following error word. This step is accomplished by reading the number of counts accumulated in the up/down command and feedback counters during the last cycle. These data are converted into two 32-bit words that have least-significant-bit values of $25.4 \mathrm{fm}$ (1 pin). The two words are then subtracted and the upper 16 bits of the result are output to the digital-to-analog converter. The remaining 16 bits are saved for use in the next following error calculation.

The control software performs the following error calculation on a continuous basis, and the overall program cycle time is dependent on the number of counts being processed in any

(b) The exact value depends on ambient temperature, pressure, and humidity. 
given time period. However, the basic cycle time required to update the following error word is approximately $1.5 \mathrm{~ms}$; and, as a result, only a few feedback and command counts need to be processed in each cycle at feedrates below $0.1 \mathrm{ipm}$. In addition, the interface counters have sufficient capacity to accommodate sudden disturbances to the system.

\section{Servo System}

The servo system, which is based on the Inland EM-1804 100-watt transistorized servo drive, is diagramed in Figure 6. The system utilizes lag compensation and acceleration feedback to provide stability along with a high-position loop gain. Velocity feedback was initially tried; however, it had a destabilizing effect, and acceleration feedback was found to be much more suitable.

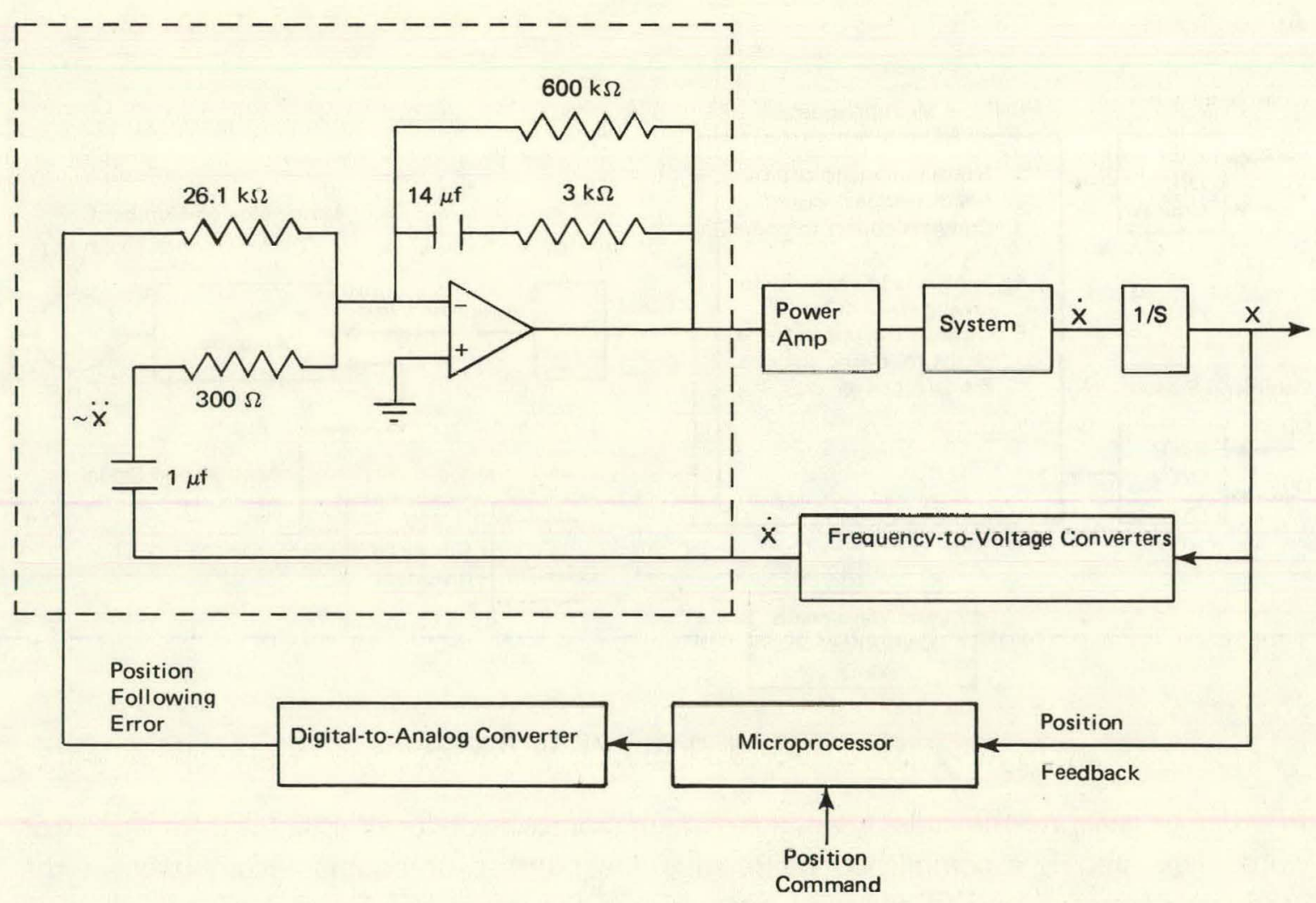

Figure 6. COMPONENTS OF THE SERVO SYSTEM.

Because the linear motor has no rotating components, it is not feasible to use a tachometer to provide an accurate rate signal. Instead, the laser up/down pulses are coupled to individual frequency-to-voltage (F/V) converters to generate an analog signal. The output of the F/Vs is then summed to provide an analog velocity signal, as shown in Appendix $C$. The negative acceleration feedback signal is simulated by coupling the rate signal to the servo amplifier through a series capacitor. 


\section{Results}

Initially, the servo system was configured for a position-and-velocity loop. However, it was found that, except for the case of a very low system gain, a stability problem existed due to the large slide mass and very low system friction. Lag compensation provided some increase in stability, but not enough to provide suitable operation.

Conversion of the velocity loop to an acceleration loop resulted in greatly increased stability; and, when combined with lag compensation, yielded a position loop gain of approximately $100 \mathrm{ipm} / \mathrm{mil}$ of following error. Figure 7 shows the system following error response to an analog step input at the servo system.

Figure 8 shows the system following error for three different feed-rate commands that were generated by presenting pulse trains to the microprocessor command input interface. Over the feed-rate range of 0.001 to $0.1 \mathrm{ipm}$, the positioning uncertainty of the system varied from about 150 to 200 $\mathrm{nm}(6-8 \mu \mathrm{in})$, with a fundamental frequency of about $60 \mathrm{~Hz}$. Figure 9 shows the system following error at slide standstill under three conditions: View a, with the control power on; View $b$, with the control power off,

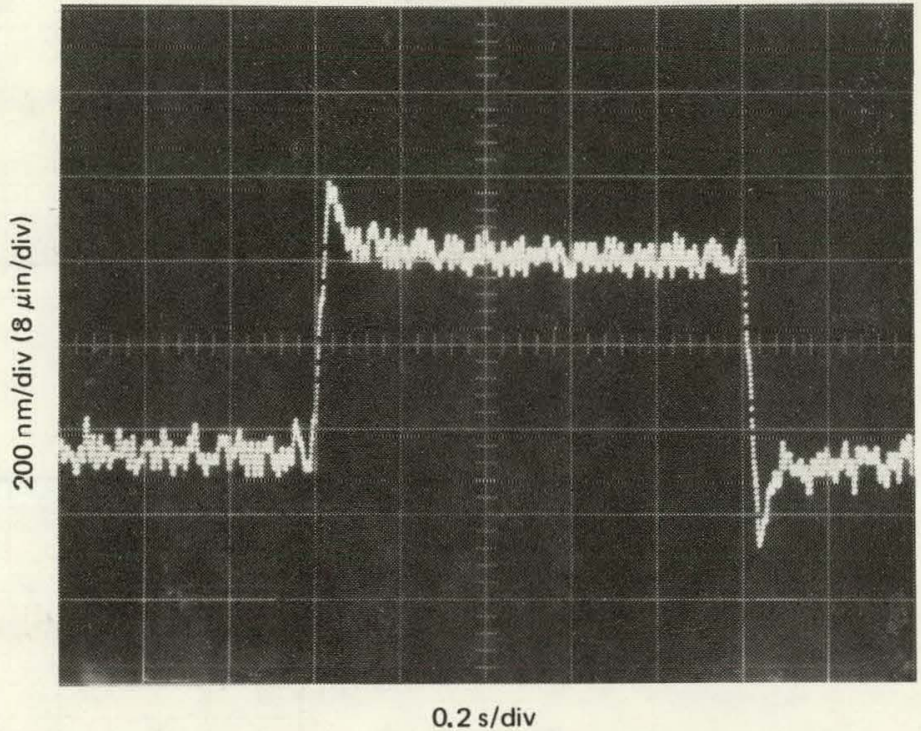

Figure 7. SYSTEM-FOLLOWING-ERROR RESPONSE TO STEP INPUT AT THE SERVO AMPLIFIER. and View c, with the air to the slide off and the control power off. A comparison of the vibration levels observed with the control power on and off indicated that the oscillation was not originating within the servo system. View c of Figure 8 indicates that the table top itself was behaving as a relatively rigid body. This and other supplemental data indicated that the positioning uncertainty was caused primarily by building structural vibration that was easily transmitted through the air bearing and appeared as an axial disturbance of 100 to $150 \mathrm{~nm}$ (4-6 $6 \mathrm{in}$ ).

A pneumatic vibration isolation system was used to reduce the level of external disturbance. Figure 10 shows the variation in the present system following error at standstill and at feedrates between 0.001 and $0.1 \mathrm{ipm}$. The static positioning uncertainty is seen to be \pm 1 feedback count, or $\pm 16 \mathrm{~nm}( \pm 0.6 \mu \mathrm{in})$, at standstill. At a feedrate of $0.001 \mathrm{ipm}$, the positioning uncertainty increases to approximately $53 \mathrm{~nm}(2.1 \mu \mathrm{in})$; while, at the higher feedrates of 0.01 and $0.1 \mathrm{ipm}$, the positioning uncertainty decreases back to the \pm 1 feedback count level. 


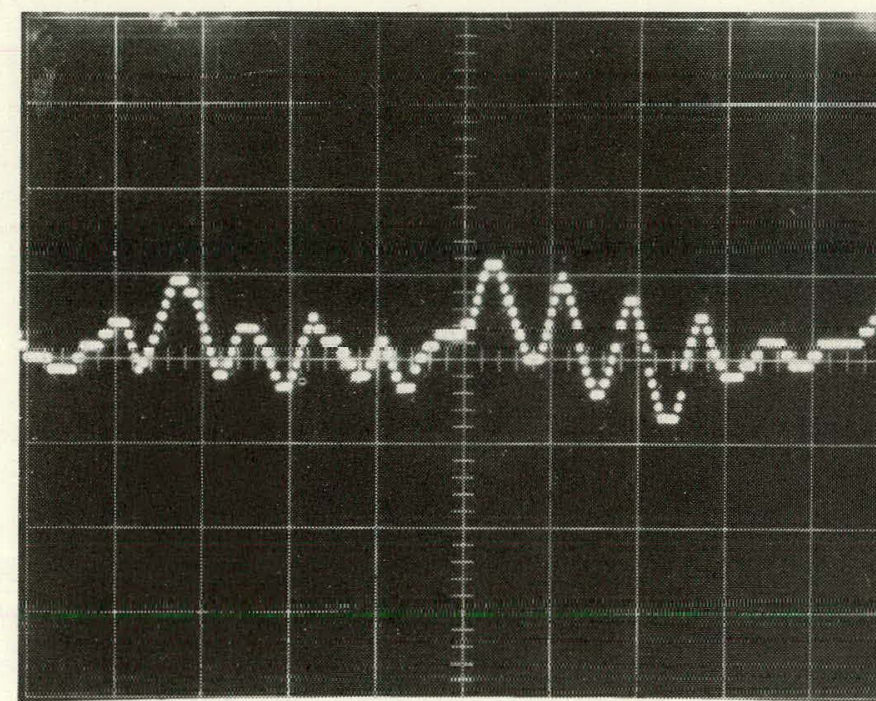

(a) At $0.001 \mathrm{ipm}$.

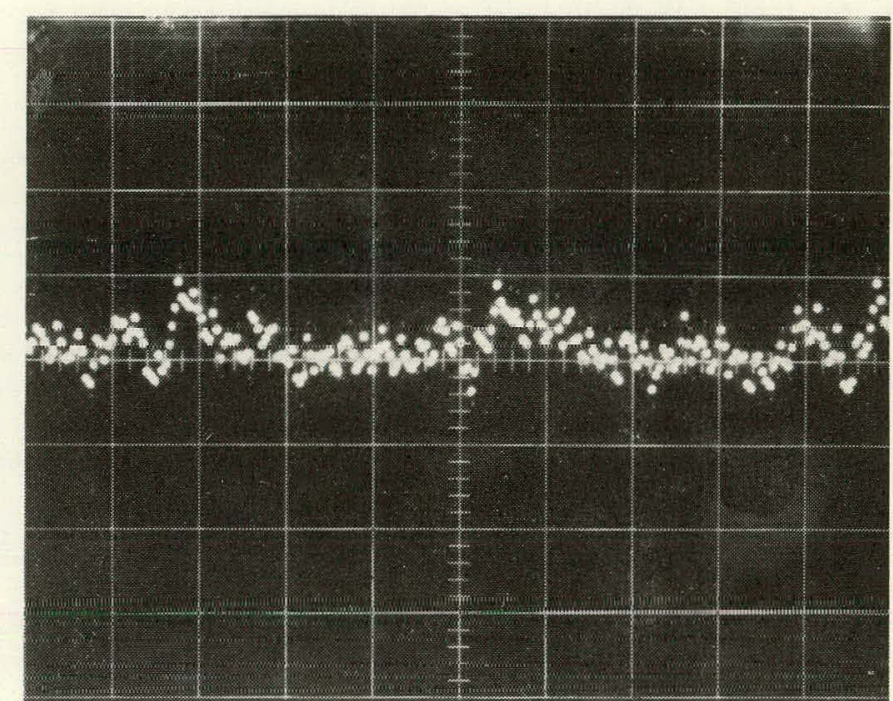

(b) At $0.01 \mathrm{ipm}$.

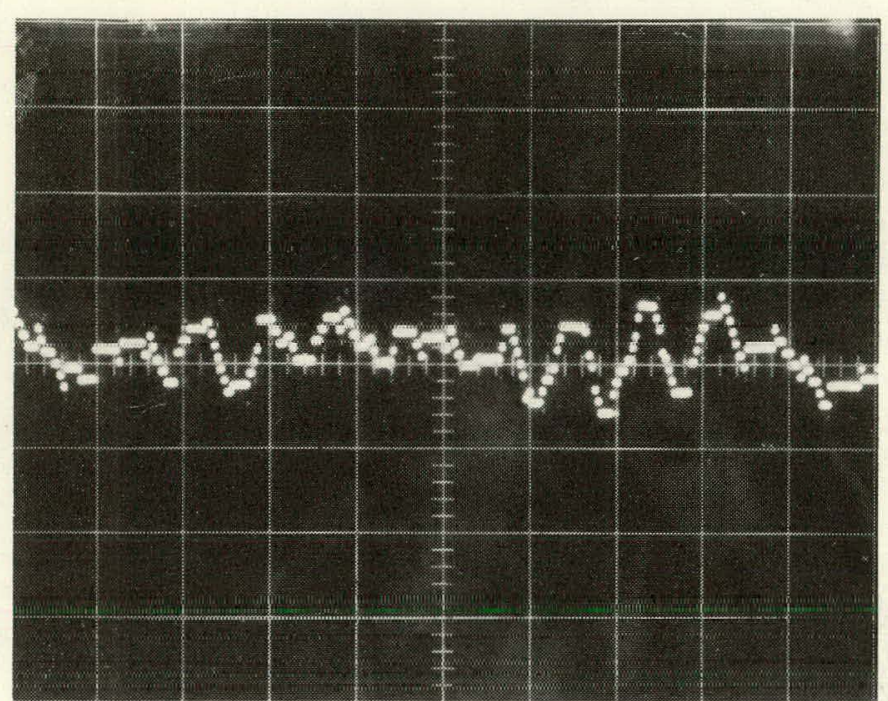

(c) At $0.1 \mathrm{ipm}$.

Figure 8. SYSTEM FOLLOWING ERROR FOR A CONSTANT/FEEDRATE COMMAND. [Each Horizontal Division Equals $20 \mathrm{~ms} / \mathrm{div}$; Each Vertical Division Equals $100 \mathrm{~nm} / \mathrm{div}(4 \mu \mathrm{in} / \mathrm{div})$ ]

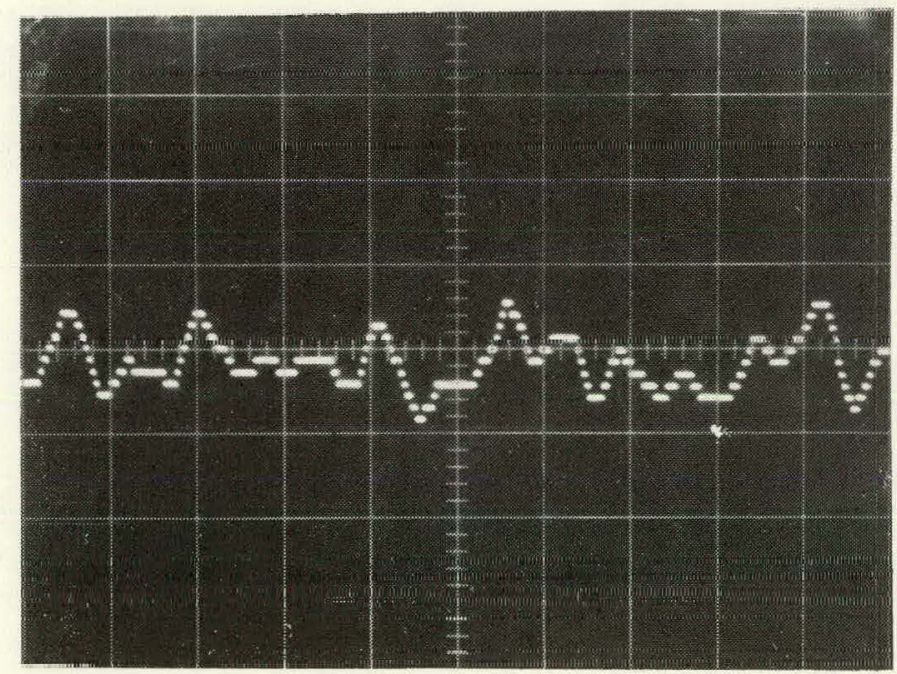

(a) With the Control Power On.

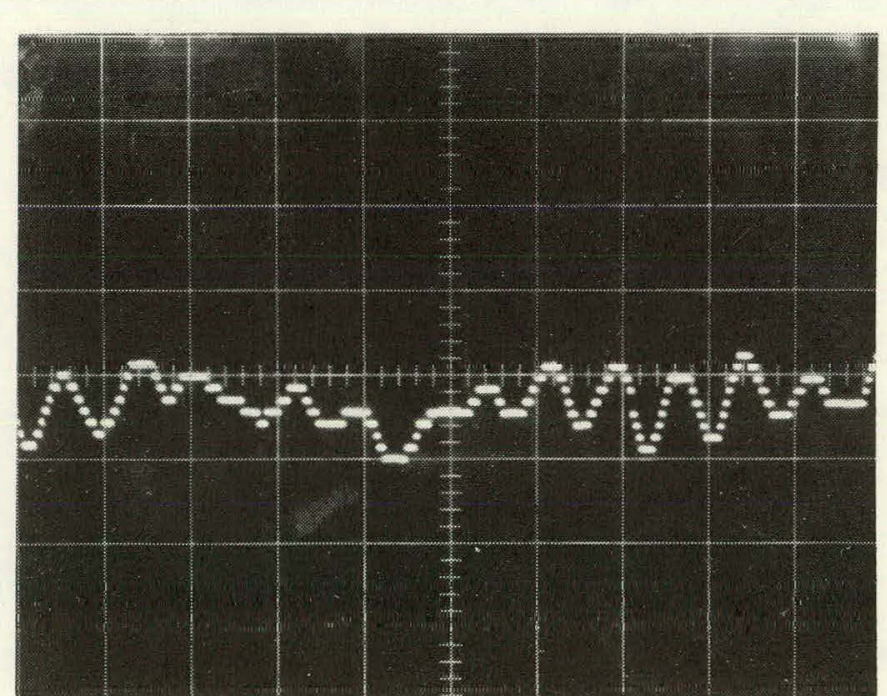

(b) With the Control Power Off.

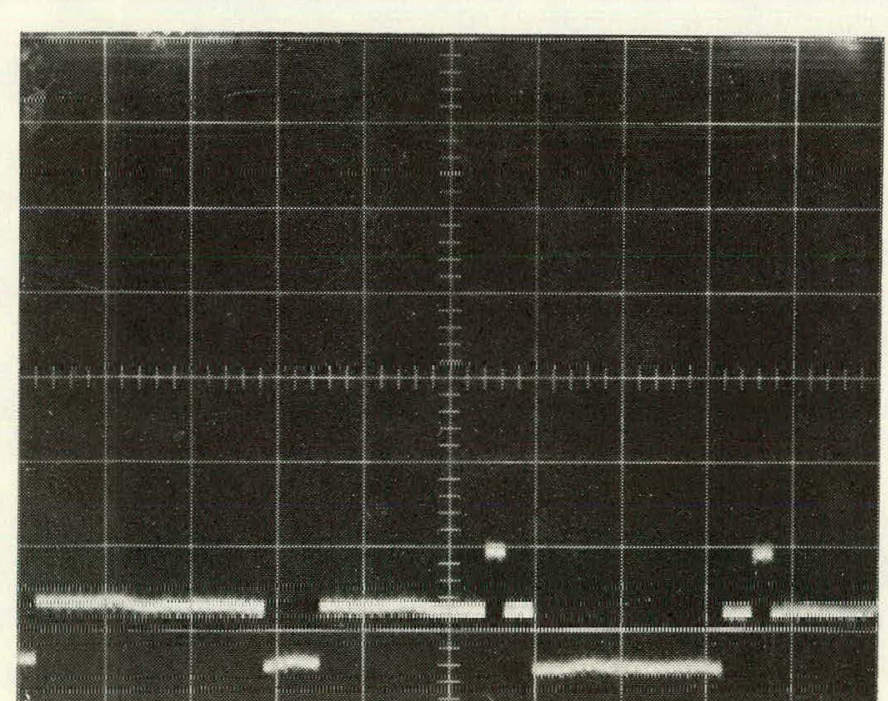

(c) With Both the Control Power and Slide Air Off.

Figure 9. SYSTEM FOLLOWING ERROR AT STANDSTILL. [Each Horizontal Division Equals $20 \mathrm{~ms} /$ div; Each Vertical Division Equals $100 \mathrm{~nm} / \mathrm{div}(4 \mu \mathrm{in} / \mathrm{div})]$

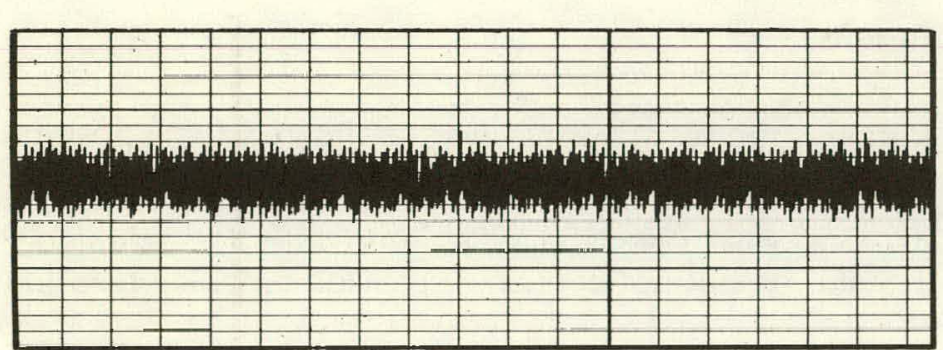

(a) At $0.001 \mathrm{ipm}$.

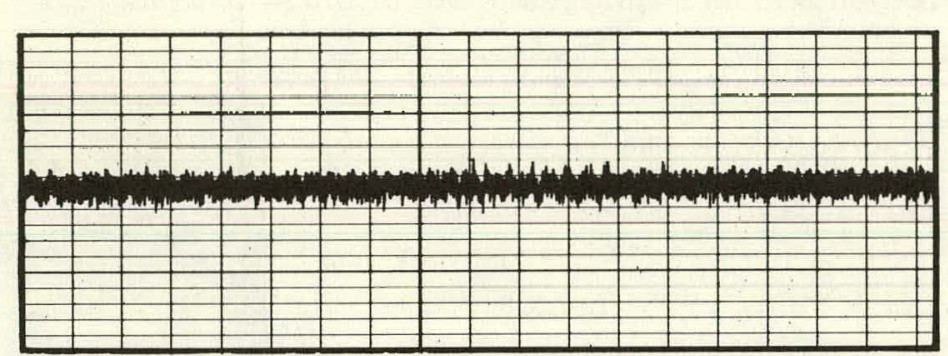

(b) At $0.01 \mathrm{ipm}$.

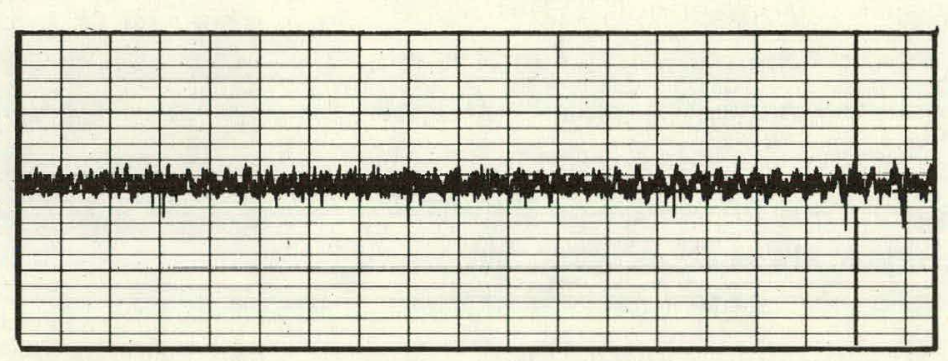

(c) At $0.1 \mathrm{ipm}$.

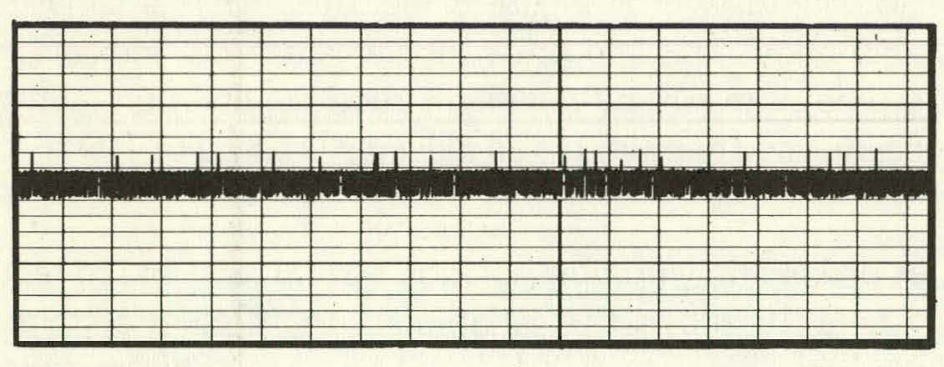

(J) At Stantusill.

Figure 10. SYSTEM FOLLOWING ERROR WITH THE ISOLATION SYSTEM INSTALLED. [Each Vertical Division Equals $5 \mathrm{~nm} /$ div $(0.2$
$\mu$ in/div): Chart Speed, $5 \mathrm{~mm} / \mathrm{s}$ ] 


\section{CONCLUSIONS}

Because of the successful results obtained with the $510 \mathrm{~mm}(20 \mathrm{in})$ linear motor, plans have been made to investigate a longer travel motor for use with a large diamond turning machine. The new motor will also be capable of exerting an axial force of $90 \mathrm{~N}(20 \mathrm{lb})$, and will have a travel of $854 \mathrm{~mm}$ (34 in). The associated control system will have a command resolution of $25.4 \mathrm{~nm}(1 \mu \mathrm{in})$.

The original control system was initially configured for a 254-nm (10- $\mu$ in) command resolution, and it will be necessary to expand the microprocessor interface to provide a suitable 25.4-nm (1- $\mu$ in) operation:

Altering the system resolution to the 25.4-nm (1- $\mu \mathrm{in})$ and lower levels does not require increased word length in the processor calculations as long as the servo loop is sufficiently tight and/or the processor speed is adequate, but it does require an increased interface capacity since the command and feedback pulses are now accumulated much faster for a given feedrate command.

Following the expansion of the processor interface, the feedback pulse resolution limit will be investigated using an additional laser interferometer resolution extender and, possibly, more involved compensation networks. In addition, the processor capability for multiaxis control and other data-handling tasks will be evaluated. Finally, incorporation of the linear-induction-motor drive system into a machine tool will be investigated; however, this effort will require special consideration of the unique features of this drive system.

One of the unusual features of this drive system is the strong, local magnetic field associated with the motor stator. Care must be taken during the design phase of the basic machine tool to ensure that this does not interfere with the system operation. Another unique system constraint and advantage is the lack of a lead screw. This arrangement permits a smooth drive motion, but also provides no stopping mechanism in the event of an emergency stop condition such as slide runaway due to loss of feedback signal. A positive braking technique will be needed with the slide system to provide a definite stopping action whenever needed. 
14

APPENDIX A

FORCE CHARACTERISTIC

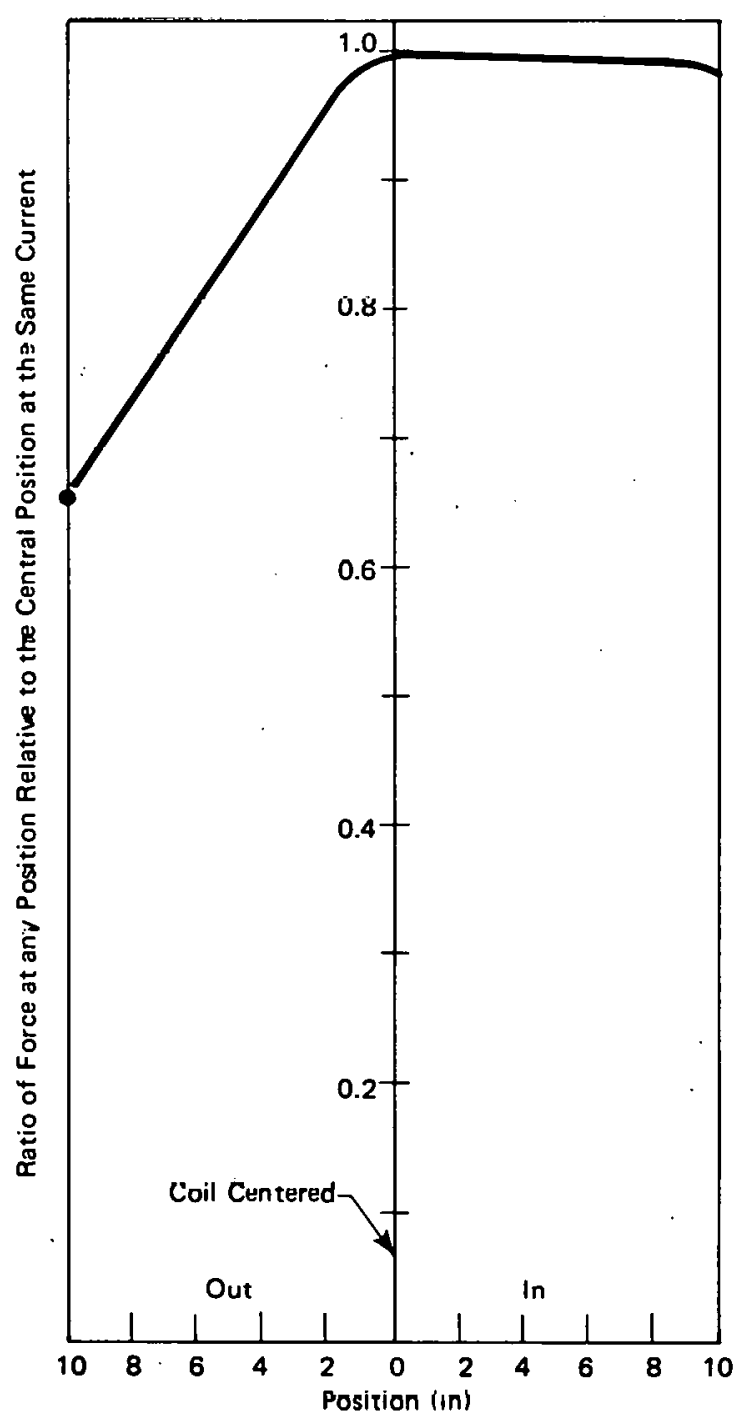

Figure A=1. APPRDXIMATE FORCE RATIO AS A FUNCTION OF THE POSITION FOR A SMALL CURRENT $(<0.1$ A). 


\section{APPENDIX B}

\section{SOFTWARE DOCUMENTATION}

The slide control software consists of the following subroutines which are described in detail in the subtopics to follow.

Subroutine

$\begin{aligned} 1 & \text { Laser Compensation } \\ 2 & \text { Initialization } \\ 3 & \text { Read Feedback (FB) Counts (CTS) } \\ 4 & \text { FB CTS Conversion } \\ 5 & \text { Negative FB Value Conversion } \\ 6 & \text { FB Value Storage } \\ 7 & \text { Read Command (CMD) CTS } \\ 8 & \text { CMD CTS Conversion } \\ 9 & \text { Positive CMD Value Conversion } \\ 10 & \text { Following Error (FE) Calculation } \\ 11 & \text { FE Output } \\ 12 & \text { Algorithm Logic }\end{aligned}$

A BCD Laser Compensation Constant is read from a thumb wheel switch and converted to its binary equivalent. The $\mathrm{FB}$ and $\mathrm{CMD}$ constants are then stored in memory for use during the $\mathrm{FB}$ and $\mathrm{CMD}$ value conversions. The software converts the $\mathrm{FB}$ and $\mathrm{CMD}$ input counts into a 32-bit binary word where the least significant bit (LSB) represents $1 \times 10^{-12}$ inches. The most significant bit (MSB) is Bit 31 ; Bit 32 is a sign bit. Following the FB and CMD to microinches conversion, the following error is calculated and output to the D/A converter. The software calculates - FE.

\section{Laser Compensation (Subroutine 1)}

The three-digit binary coded decimal (BCD) laser compensation value $(1 / 4 \lambda)$ is input via Port 15 and the upper four bits of Port 14. The least significant digit (LSD) is loaded into the $E$ register while the other two digits are left in the A register.

The A-register word is then shifted left and a carryout check is made. If the carryout occurs, the binary equivalent of the weight of the particular bit is loaded into the HL register pair and added to the contents of the DE register pair. The process is continued until each bit of the $B C D$ laser compensation word has been tested and the binary equivalent of the $B C D$ value has been formed in the DE register pair.

\section{Initialization (Subroutine 2)}

The two 16-bit following error words are initially set to zero. FEMIL is the upper 16-bit word and FESUB is the lower 16-bit word. (Only FEMIL is output to the D/A.) 
Table B-1

SOFTWARE FOR SUBROUTINE 1

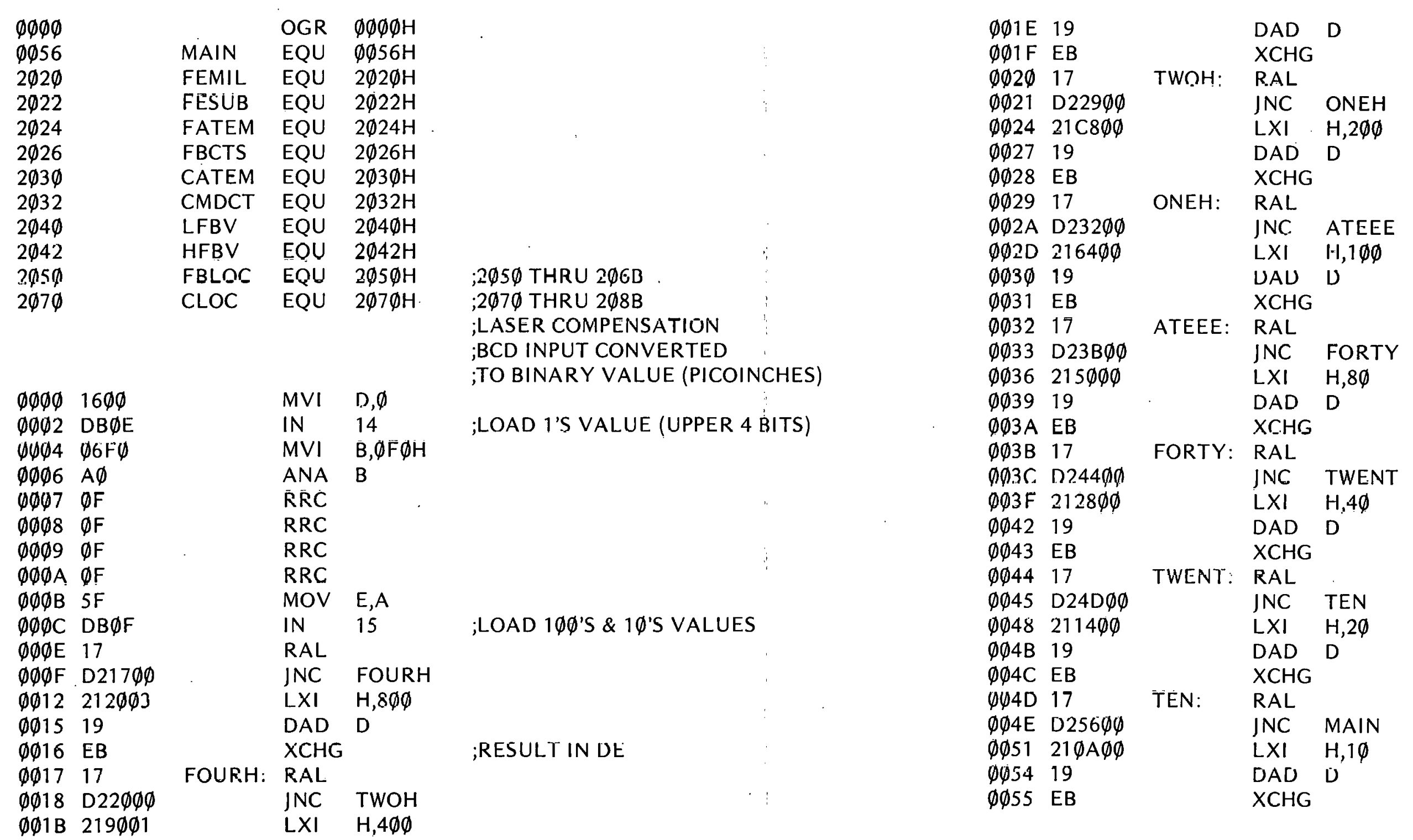

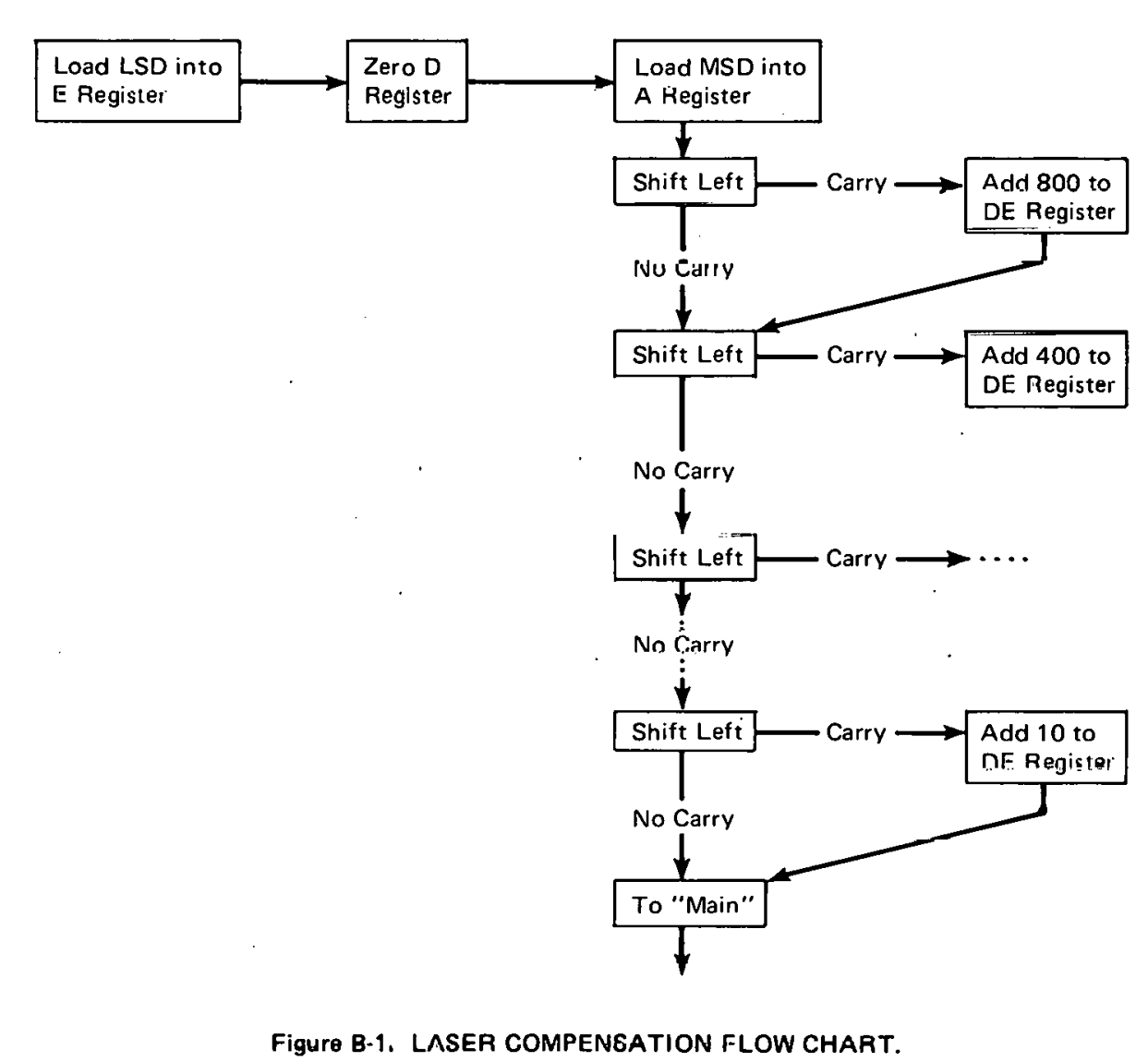

;LASER COMP. IN DE 
Table B-2

SOFTWARE FOR SUBROUTINE 2

;INITIALIZATION

\section{$\emptyset \emptyset 5621 \emptyset \emptyset \emptyset \emptyset$}

$\emptyset \emptyset 59222 \emptyset 2 \emptyset$

$\emptyset \emptyset 5 \mathrm{~F} 212 \emptyset \emptyset 8$

$\emptyset \emptyset 6219$

$\emptyset \emptyset 64 \quad 215 \emptyset 2 \emptyset$

$\begin{array}{lll}0067 & 73 \\ 0068 & 23\end{array}$

$\begin{array}{ll}0668 \quad 23 \\ 0069 & 72\end{array}$

$\emptyset 06972$

$\begin{array}{ll}\emptyset \varphi 6 \mathrm{~A} & 23 \\ \emptyset \emptyset 6 \mathrm{~B} & 365 \mathrm{~F}\end{array}$

$\begin{array}{ll}\emptyset \emptyset 6 \mathrm{~B} & 365 \mathrm{~F} \\ \emptyset \emptyset 6 \mathrm{D} & 23\end{array}$

$\begin{array}{ll}\emptyset \emptyset 6 \mathrm{E} & 36 \emptyset \emptyset \\ \emptyset \emptyset 7 \emptyset & 23\end{array}$

$\begin{array}{ll}\emptyset \emptyset 7 \emptyset & 23 \\ \emptyset \emptyset 71 & 7 \mathrm{~B}\end{array}$

907242

$\emptyset \emptyset 7316 \emptyset \emptyset$

$\emptyset 975$ QЕ.5F

$\emptyset \emptyset 77$ 1Е $\emptyset 6$

$\emptyset \emptyset 79 \quad 37$

$\begin{array}{ll}\emptyset \emptyset 7 \mathrm{~A} & 3 \mathrm{~F} \\ \emptyset \emptyset 7 \mathrm{~B} & 17\end{array}$

$97 \mathrm{C} \quad 32242$

$97 \mathrm{~F} 77$

$\varphi 98 \emptyset 78$

$\emptyset 981 \quad 23$

$\emptyset 982 \quad 17$

$\varphi \varphi 83 \quad 77$

$\begin{array}{lll}9084 & 47\end{array}$

$9085 \quad 23$

$9 \emptyset 86 \quad 79$

$\emptyset 987 \quad 17$

$0988 \quad 77$

$\emptyset \emptyset 8923$

$\emptyset \emptyset 8 \mathrm{~A} 4 \mathrm{~F}$

$\emptyset \emptyset 8 \mathrm{~B} 7 \mathrm{~A}$

$\emptyset 98 \mathrm{C} 17$

Ф98D 77

$\emptyset \emptyset 8 \mathrm{E} 23$

690 . 3A242

$\emptyset \emptyset 9 \emptyset \cdot 3 \mathrm{~A} 242 \emptyset$

\begin{tabular}{|c|c|c|c|}
\hline \multirow[t]{3}{*}{ MAIN: } & LXI & $H, \emptyset$ & \\
\hline & SHLD & FEMIL & ;ZERO CURRENT FOLLOWING ERROR \\
\hline & SHLD & FESUB & ;ZERO CURRENT FOLLOWING ERROR \\
\hline \multirow[t]{2}{*}{$\cdot$} & LXI & $\mathrm{H}, \emptyset 82 \emptyset \mathrm{H}$ & \\
\hline & DAD & D & ;FORM FB CONVERSION CONSTANT \\
\hline & $\mathrm{XCHG}$ & & \\
\hline & LXI & H,FBLOC & \\
\hline & MOV & $\mathrm{M}, \mathrm{E}$ & \\
\hline \multirow{11}{*}{ ". } & INX & $H$ & 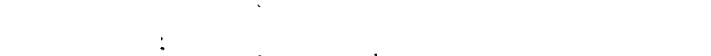 \\
\hline & MOV. & $M, D$ & \\
\hline & INX & $\mathrm{H}$ & \\
\hline & MVI & $\mathrm{M}, 5 \mathrm{FH}$ & ;FB BASE CONSTANT \\
\hline & INX & $\mathrm{H}$ & \\
\hline & MVI & $M, \emptyset$ & ;BASIC FB CONSTANT IS STORED \\
\hline & INX & $\mathrm{H}$ & \\
\hline & MOV & $A, E$ & \\
\hline & MOV & $B, D$ & . \\
\hline & MVI & $D, \emptyset$ & \\
\hline & MVI. & $\mathrm{C}, 5 \mathrm{FH}$ & \\
\hline & MVI & $E, 6$ & ;DCBA \\
\hline \multirow{23}{*}{ FCLOP: } & STC & & ;SHIFTED CONSTANTS ARE FORMED \\
\hline & CMC & & \\
\hline & RAL & & \\
\hline & STA & FATEM & \\
\hline & MOV & $\mathrm{M}, \mathrm{A}$ & . \\
\hline & MOV & $A, B$ & \\
\hline & INX & $\mathrm{H}$ & \\
\hline & RAL & & \\
\hline & MOV & $M, A$ & \\
\hline & MOV. & $B, A$ & \\
\hline & InX & $H$ & \\
\hline & MOV & $A, C$ & \\
\hline & RAL & & \\
\hline & MOV. & $M, A$ & \\
\hline & INX & $\mathrm{H}$ & \\
\hline & MOV & C,A & $\cdot$ \\
\hline & MOV & $A, D$ & \\
\hline & RAL & & \\
\hline & MOV & $\mathrm{M}, \mathrm{A}$ & \\
\hline & INX & $H$ & \\
\hline & MOV & $\mathrm{D}, \mathrm{A}$ & \\
\hline & LDA & FATEM & ;DCBA AND MEMORY \\
\hline & DCR & $E$ & \\
\hline
\end{tabular}

$\emptyset \emptyset 94$ C279фф

$\emptyset \emptyset 97 \quad 217 \emptyset 2 \emptyset$

$\emptyset \emptyset 9 \mathrm{~A} 1 \mathrm{E} 8 \emptyset$

$\emptyset \emptyset 9 \mathrm{C} 73$

$\emptyset \emptyset 9 D 23$

ФФ9E 1696

$\emptyset \emptyset \mathrm{A} \emptyset 72$

$\emptyset \emptyset \mathrm{A} 123$

$\emptyset \emptyset \mathrm{A} 2 \emptyset \mathrm{E} 98$

$\emptyset \emptyset \mathrm{A} 471$.

ФФА 23.

$\emptyset \emptyset \mathrm{A} 523$

$\emptyset \emptyset \mathrm{A} 67 \mathrm{~B}$

$\emptyset \emptyset A 816 \emptyset \emptyset$

$\emptyset \emptyset A A 36 \emptyset \emptyset$

$\emptyset \emptyset \mathrm{AC} 23$

$\emptyset \emptyset \mathrm{AD} 1 \mathrm{E} \emptyset 6$

$\emptyset \emptyset A F \quad \emptyset \emptyset$

$\emptyset \emptyset \mathrm{B} \emptyset 37$

$\emptyset \emptyset \mathrm{B} 13 \mathrm{~F}$

$\emptyset \emptyset \mathrm{B} 2 \quad 17$

$\emptyset \emptyset \mathrm{B} 3 \quad 323 \emptyset 2 \emptyset$

ф६B 77

$\emptyset \emptyset \mathrm{B} 778$

Ф९В8 23

ф६B 917

$\emptyset \emptyset \mathrm{BA} 77$

$\emptyset \emptyset \mathrm{BB} \quad 47$

$\emptyset \emptyset \mathrm{BC} 23$

Ф९BD 79

Ф६ВE 17

ФQBF 77

ФणC口 23

$\emptyset \emptyset \mathrm{C1} 14 \mathrm{~F}$

$\emptyset \emptyset \mathrm{C2} 2 \mathrm{AA}$

$\emptyset \emptyset \mathrm{C} 3 \quad 17$

$\emptyset \emptyset \mathrm{C5} 23$

фøC6 57

$\emptyset \emptyset \mathrm{CC} \quad 3 \mathrm{~A} 302$

ФФСA 1D
LXI H,CLOC

MVI $\quad E, 8 \emptyset \mathrm{H}$

MOV M,E

INX

MVI D,96H

MOV M,D

INX $\mathrm{H}$

$\mathrm{MVI} \mathrm{C} 98 \mathrm{H}$

MOV M,C

MOV $\mathrm{A}$

MOV A,E

MOV B,D

MVI D, $\varnothing$

MVI M,

INX $\mathrm{H}$

MVI E,6

CCLOP: STC

STC
CMC

RAL

STA CATEM

MOV M,A

MOV A,B

INX $\mathrm{H}$

RAL

MOV M,A

MOV B,A

INX $\mathrm{H}$

MOV A,C

RAL

MOV M,A

INX $\mathrm{H}$

MOV C,A

MOV A, D

MOV

RAL

INX $\mathrm{H}$

MOV DA

LDA CATEM

$\begin{array}{ll}\text { LDA } & \text { CATE } \\ \text { DCR } & \text { E }\end{array}$

INZ CCLOP
;CMD CONSTANT INITIALIZATION 
Prior to the calculation of the 32-bit following error word (LSB = 1 pin), the contents of the FB and CMD counters are converted into 32-bit words through a process of shifting the $\mathrm{FB}$ and $\mathrm{CMD}$ words and adding when a carryout occurs.

The constants used in the summation process are stored in memory by the initialization part of the control program. The first merriory location used to store the low order part of the constant is FBLOC (FB) and CLOC (CMD).

The constant which corresponds to the binary equivalent of the LSB of the FB or CMD counter is stored in memory and also shifted to form the other constants which correspond to the other bits in the FB or CMD counter words.

The memory storage locations used for the constants are controlled by the HL register parr. This register pair is initialized to FBLOC for the FB counts and CLOC for the CMD counts. The HL pair is then incremented following each shift operation to define a new memory location.

The value of the FB constant is modified by the laser compensation value prior to the shifting process.

\section{Read Feedback Counts (Subroutine 3)}

The feedback counts (FB CTS) are transferred from the up/down counters of the buffer register by outputting a RESET and LOAD pulse to the counter interface. The reset pulse is coded as a $4 \emptyset \mathrm{H}$ output word to Port 14 , while the load pulse is coded as an $8 \emptyset \mathrm{H}$ output word to Port 14. The FB counts are then read from Port 12. If the FB counts are negative, the $A$ register is complemented and incremented and the MSR of the $B$ register is set equal to one.

\section{Fccdback Counts Conversion (Subroutine 4)}

The feedback counts in the A register are converted (FBCC) to the 32-bit binary picoinch (pin) word by forming a sum which is based on the bits present in the A register. The constants formed earlier in the initialization ses.tinn are uttilized tn nerform the rnnversinn through a procese of shifting the $A$ register, checking for a carry, and forming the approximate summation.

The HL register pair is again used to hold the memory location of the appropriate constant (beginning at FBLOC). Double-word additions using the SP register are done to check for a carryout.

Following the conversion, the sign of the B register is checked. If a positive result is obtained the program jumps to the storage of the result. If a negative result is obtained the 2s complement is formed and stored. 


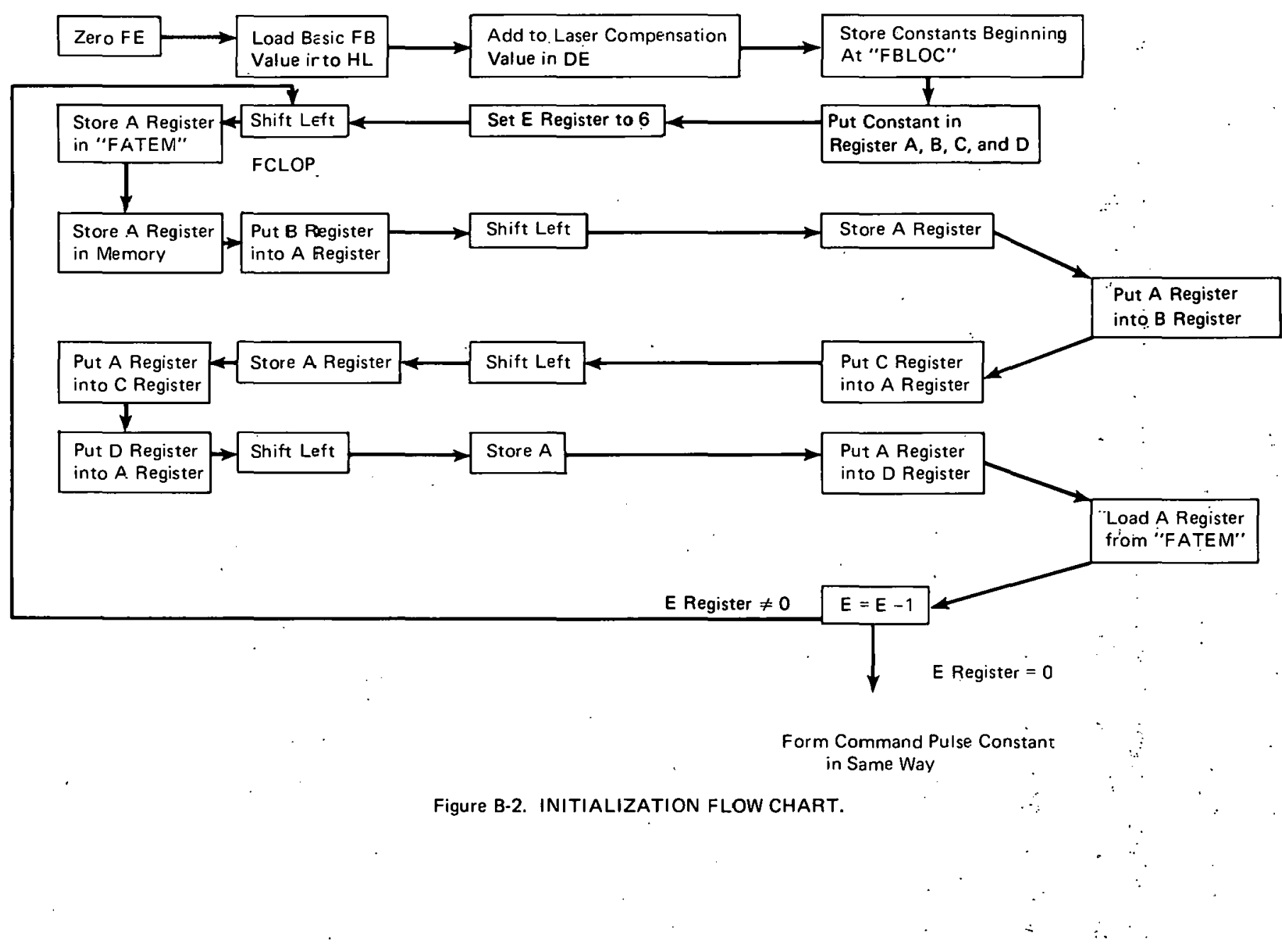




\section{Negative Feedback Value Conversion (Subroutine 5)}

A negative result is $2 \mathrm{~s}$ complemented because the conversion process does not consider the sign of the FB counts, it just performs a strict bit-for-bit conversion.

\section{Feedback Value Storage (Subroutine 6)}

The 32-bit converter feedback value is stored using the FSTOR routine. Two 16-bit words are used-LFBV and HFBV, where HFBV is the high-order 16 bits.

\section{Read Command Counts (Subroutine 7)}

This section is similar to the Read FB Counts section. Since the CMD up/down counter has already been loaded into buffer storage by the RESET and LOAD pulses generated in the Read FB counts section, it is only necessary to input the CMD CTS via Port 13.

Since $\mathrm{FB}-\mathrm{CMD}=-\mathrm{FE}$ is accomplished through addition, positive $\mathrm{CMD} C \mathrm{CTS}$ are $2 \mathrm{~s}$ complemented and the MSB of the $B$ register is set equal to one.

\section{Command Counts Conversion (Subroutine 8)}

This section is similar to the FB CTS conversion software. However, since subtraction is being implemented via $2 \mathrm{~s}$ complement arithmetic, the resulting sign check causes different things to occur. Here, if the result of the sign is positive, the result is $2 \mathrm{~s}$ complemented.

\section{Positive Command Value Conversion (Subroutine 9)}

The positive conversion (PCVC) result is changed to the $2 \mathrm{~s}$ complement form as was done in the Negative feedback Value Conversion section (Subroutine 5).

\section{Following Error Calculation (Subroutine 10)}

The result from the CMD counts conversion is placed in registers DESP. The low-order 16 bits from the FB counts conversion, LFRV, are placed in $H L$ and added to the contents of SP. If a carry occurs, the register pair DE is incremented. The 16 high-order bits, HFRV, are then used to complete the calculation. This step calculates the difference between the FB and CMD CTS for the current sample increment.

The true following error (FE) is then calculated (FECAL) by adding the results of the present calculation to the results of the previous calculations. The result is stored in FEMIL (high-order 16 bits) and FESUB (low-order 16 bits). Only FEMIL is output to the D/A.

\section{Following Error Output (Subroutine 11)}

The upper 16 bits of the 32-bit following error word (FEMIL) are output via Ports 12 and 13. The MSB of FEMIL is complemented in software to accommodate the offset binary format of the 16-bit D/A converter. 
Table B-3

SOFTWARE FOR SUBROUTINES 3.6

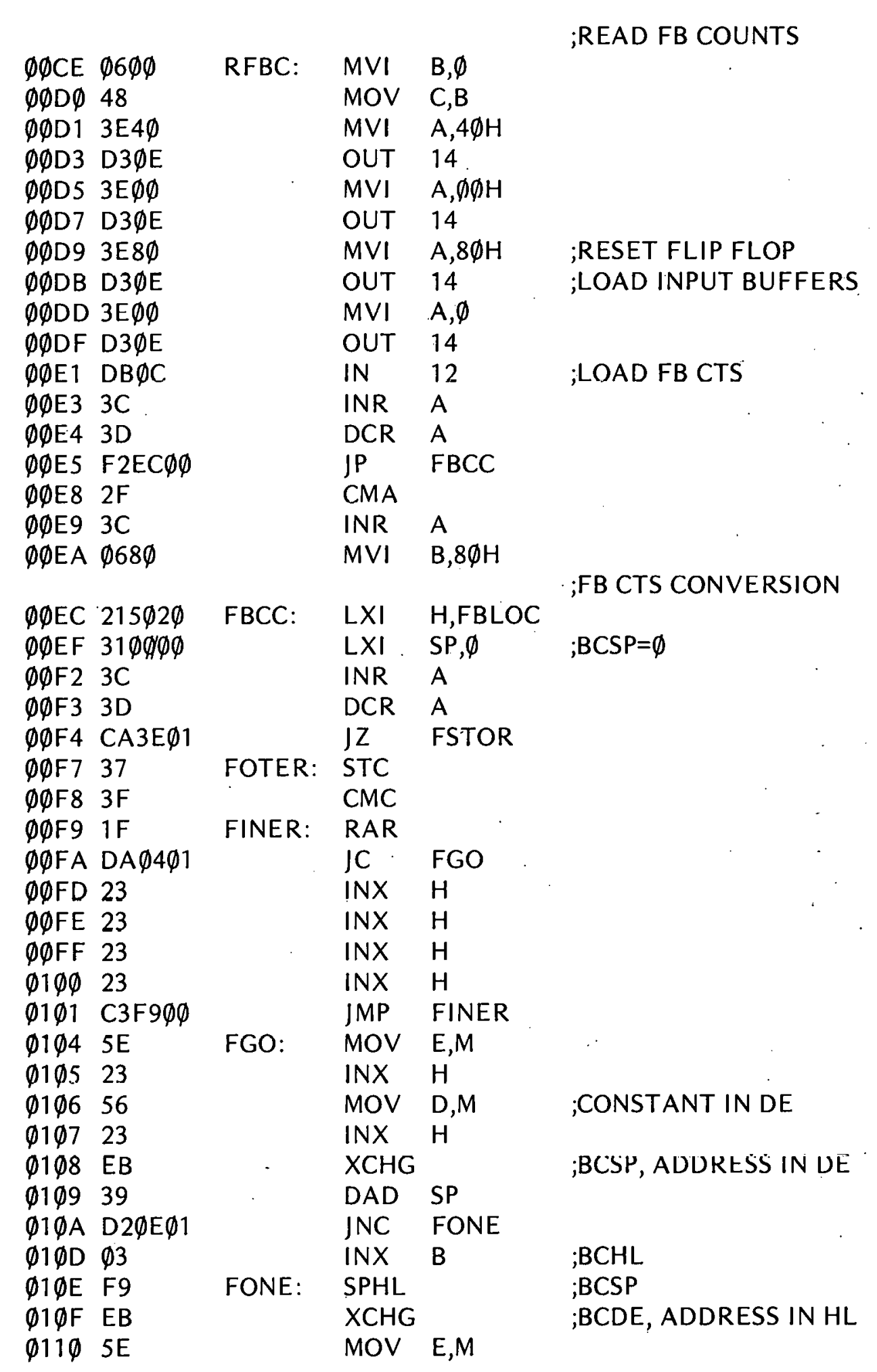

\begin{tabular}{|c|c|c|c|c|}
\hline \\
\hline & INX & & CONSTANT IN DE \\
\hline \multicolumn{2}{|l|}{ 11.3 23} & INX & H,M & ; CONSTANT IN DE \\
\hline & XCHG & & ;BCSP, ADDRESS IN HL \\
\hline \multirow{2}{*}{\multicolumn{2}{|c|}{$\begin{array}{ll}\emptyset 115 & \emptyset 9 \\
0116 & 44\end{array}$}} & DAD & & ; HLSP \\
\hline & MOV & $\mathrm{B}, \mathrm{H}$ & \\
\hline & & & & \\
\hline \multirow{2}{*}{\multicolumn{2}{|c|}{$\emptyset 118 \mathrm{~EB}$}} & XCHG & & ;BCSP, ADDRESS IN HL \\
\hline \multirow{2}{*}{\multicolumn{2}{|c|}{$\begin{array}{ll}\emptyset 119 & 3 \mathrm{C} \\
\emptyset 11 \mathrm{~A} & 3 \mathrm{D}\end{array}$}} & INR & A & \\
\hline & & DCR & & \\
\hline \multicolumn{5}{|c|}{ 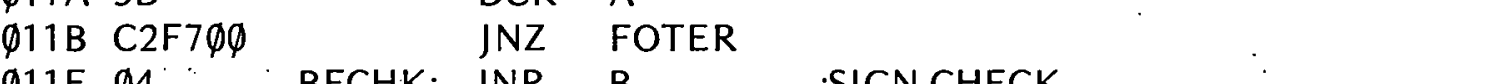 } \\
\hline$\emptyset 11 \mathrm{E} \emptyset 4$ & BFCHK: & INR & & ;SIGN CHECK \\
\hline \multirow{2}{*}{$\begin{array}{l}\emptyset 11 F \emptyset 5 \\
\phi 12 \emptyset \mathrm{F} 23 \mathrm{E} \phi 1\end{array}$} & & $\underset{\text { DCR }}{\text { DCR }}$ & 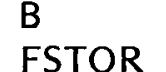 & \\
\hline & & & & ;NEGATIVE FB VALUE CONVERSION \\
\hline \multirow{2}{*}{\multicolumn{2}{|c|}{ 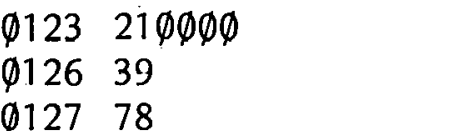 }} & $\begin{array}{l}\text { LXI } \\
\text { DAD }\end{array}$ & $\begin{array}{l}\text { H,Q } \\
S P\end{array}$ & \\
\hline & & MOV & $A, B$ & ;ACHL \\
\hline \multicolumn{2}{|l|}{$\emptyset 128 \quad 17$} & RAL & & \\
\hline \multirow{2}{*}{\multicolumn{2}{|c|}{$\begin{array}{l}\emptyset 129 \quad 2 \mathrm{~F} \\
012 \mathrm{~A} 1 \mathrm{~F}\end{array}$}} & CMA & & \\
\hline & & RAR & & \\
\hline \multicolumn{2}{|l|}{ 12B 47} & MOV & B,A & \\
\hline \multicolumn{2}{|l|}{$112 C 79$} & MOV & $\mathrm{A}, \mathrm{C}$ & \\
\hline & MOV & $C, A$ & \\
\hline & & MOV & $\mathrm{A}, \mathrm{H}$ & \\
\hline & CMA & & \\
\hline \multicolumn{2}{|l|}{$1131 \quad 67$} & MOV & $\mathrm{H}, \mathrm{A}$ & \\
\hline \multicolumn{2}{|l|}{$01327 \mathrm{D}$} & MOV & $A, L$ & \\
\hline \multirow{2}{*}{\multicolumn{2}{|c|}{$91332 \mathrm{~F}$}} & CMA & & \\
\hline & & MOV & $L, A$ & ;BCHL \\
\hline \multicolumn{2}{|l|}{$013531 \emptyset 1 \emptyset \emptyset$} & LXI & $S P, 1$ & \\
\hline \multicolumn{2}{|l|}{13839} & DAD & & \\
\hline \multicolumn{2}{|l|}{$\begin{array}{l}\emptyset 139 \mathrm{D} 23 \mathrm{D} \emptyset 1 \\
\emptyset 13 \mathrm{C}\end{array}$} & $\begin{array}{l}\text { JNC } \\
\text { INI }\end{array}$ & FONMO & \\
\hline \multirow[t]{2}{*}{ ब13D F9 } & FONMO: & $\begin{array}{l}\text { INX } \\
\text { SPHL }\end{array}$ & & ;BCSP IN 2'S COMPLEMENT FORM \\
\hline & & & & ;FB VALUE STORAG \\
\hline \multirow{4}{*}{$\begin{array}{ll}\varphi 13 E & 21 \emptyset \phi \emptyset \phi \\
\emptyset 141 & 39 \\
\emptyset 142 & 224 \phi 2 \emptyset \\
\emptyset 145 & 6 \emptyset \\
\emptyset 146 & 69 \\
\emptyset 147 & 22422 \emptyset\end{array}$} & & DAD & SP & \\
\hline & & SHLD & LFBV & ;BCHL \\
\hline & & MOV & $\mathrm{H}, \mathrm{B}$ & \\
\hline & & $\begin{array}{l}\text { MOV } \\
\text { SHLD }\end{array}$ & $\begin{array}{l}\mathrm{L}, \mathrm{C} \\
\mathrm{HFBV}\end{array}$ & \\
\hline
\end{tabular}

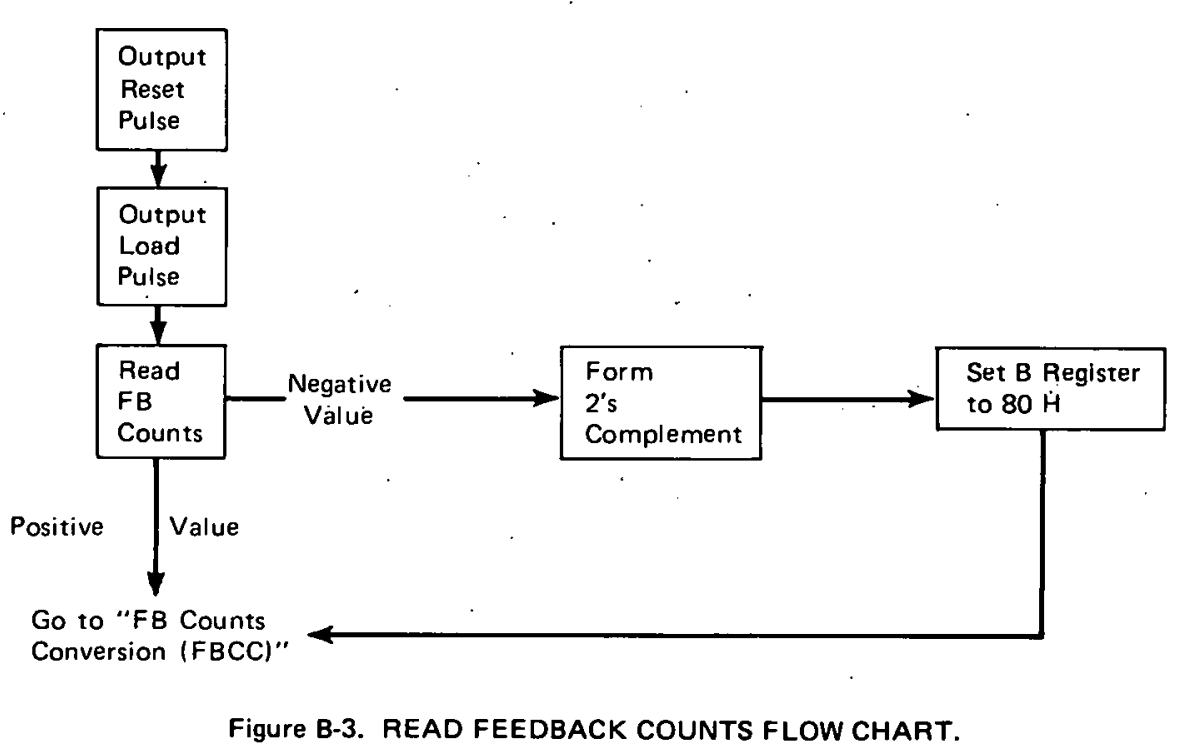


Tate $B \cdot 4$

SOFTWARE FOR SUBROUTINES 7 - 10

\begin{tabular}{|c|c|c|c|c|}
\hline \multicolumn{5}{|r|}{;READ CMD COUNTS } \\
\hline$\emptyset 14 \mathrm{~A} \emptyset 6 \emptyset \emptyset$ & & MVI & & \\
\hline $\begin{array}{lll}4 C & 48 \\
40 & 0\end{array}$ & & Mov & $C, B$ & . OAD CMDCTC \\
\hline $\begin{array}{l}014 \mathrm{D} D \mathrm{DBDD} \\
014 \mathrm{~F}\end{array}$ & & IN & 13 & ; LOAD CMD CTS \\
\hline 915030 & & DCR & & \\
\hline $\begin{array}{l}\emptyset 151 \\
\emptyset 154258 \emptyset 1 \\
\emptyset 154\end{array}$ & & IP & CMDCC & \\
\hline Q155 3C & & INR & & \\
\hline $156 \emptyset 68 \emptyset$ & & MVI & $\mathrm{B}, 8 \emptyset \mathrm{H}$ & \\
\hline$\emptyset 158 \quad 217 \emptyset 2 \emptyset$ & CMDCC: & LXI & H.CLOC & ;CMD CIS CONVERSION \\
\hline БВ $319 \varphi \phi \emptyset$ & & LXI & & \\
\hline $15 E 3 C$ & & INR & A & \\
\hline $015 F 3 D$ & & DCR & & \\
\hline$\emptyset 16 \emptyset$ СА97Ø1 & & Jz & PCVC & \\
\hline $\begin{array}{lll}\$ 163 & 37 \\
0164 & 3 F\end{array}$ & COTER: & $\begin{array}{l}\text { STC } \\
\text { CMC }\end{array}$ & & \\
\hline$\emptyset 165 \mathrm{iF}$ & CINER: & RAR & & \\
\hline $\begin{array}{l}\emptyset 166 \text { DA7øø1 } \\
\emptyset 16923\end{array}$ & & IC & ${ }_{\mathrm{H}}^{\mathrm{CGO}}$ & \\
\hline & & INX & $\mathrm{H}$ & \\
\hline & & INX & $\mathrm{H}$ & \\
\hline & & InX & & \\
\hline $16 \mathrm{D}$ C365Ø1 & & & CINER & \\
\hline $\begin{array}{ll}\emptyset 17 \emptyset & 5 \mathrm{t} \\
0171 & 23\end{array}$ & CGO: & MOV & $\stackrel{E, M}{H}$ & \\
\hline 017256 & & MOV & $\mathrm{D}, \mathrm{M}$ & ;BCSP, CONSTANT IN DE \\
\hline $\begin{array}{lll}9173 \quad 23 \\
-114\end{array}$ & & InX & $\mathrm{H}$ & \\
\hline $\begin{array}{ll}\emptyset 174 & \mathrm{~EB} \\
\emptyset 175 & 39\end{array}$ & & $\begin{array}{l}\text { XCGG } \\
\text { DAD }\end{array}$ & & ;ADDRESS IN DE \\
\hline$\emptyset 176$ D27AØ1 & & jNC & CONE & \\
\hline 17993 & & & & \\
\hline $\mathrm{F9}$ & CONE: & & & ADDRESS IN HI \\
\hline $\begin{array}{l}\text { Ø17B EB } \\
\emptyset 17 C \quad 5 .\end{array}$ & & MOV & $F, M$ & ;AUDRESS IN HL \\
\hline
\end{tabular}

917023

$\begin{array}{ll}\emptyset 17 D & 23 \\ 917 \mathrm{E} & 56 \\ \varphi 17 \mathrm{~F} & 23\end{array}$

$\begin{array}{lll}0189 & E B \\ 0181 & 0.9\end{array}$

$\emptyset 181 \emptyset 9$

$\emptyset 183$ 4D

$\emptyset 1853 \mathrm{C}$

$\emptyset 187 \mathrm{C} 263 \emptyset$

Ф18B 95

Ф18C F297థ

$\begin{array}{ll}\emptyset 18 F & 78 \\ \emptyset 19 \varphi & 17 \\ 0191 & 3 F\end{array}$

Q190 $1 \mathrm{~F}$

$\begin{array}{ll}\emptyset 193 & 47 \\ \emptyset 194 & \text { С } 3 \text { В } \emptyset 1\end{array}$

$\emptyset 197219 \emptyset \emptyset \emptyset$ PCVP:

Q19A 39
Q19B 78

Q19C $2 \mathrm{~F}$

Q19D 47
Ф19E 79

$\begin{array}{ll}\emptyset 19 \mathrm{~F} & 2 \mathrm{~F} \\ \emptyset 1 \mathrm{~A} \emptyset & 4 \mathrm{~F}\end{array}$

$\emptyset 1 A 17 C$

$\begin{array}{lll}Q 1 A 2 & 2 F \\ 01 A 3 & 67\end{array}$

$91 \mathrm{~A} 47 \mathrm{D}$

$\emptyset 1 A 6$ GF
$\emptyset 1 A 731 \emptyset 1 \emptyset \emptyset$
INX H

MOV D,M ;CONSTANTIN DE

INX $H$

:ADDRESS IN DE

DAD B

$\begin{array}{ll}\text { MOV } & B, H \\ \text { MOV } & C, L\end{array}$

${ }_{\text {INR A }}$ A

$;$; $;$ LLSP
$;$ BLSP
$;$ BCSP

;ADDRESS IN HL

$\begin{array}{ll}\text { JNZ } & \text { COTER } \\ \text { INR } & B \\ \text { DCR } & \text { B }\end{array}$

$\begin{array}{ll}\text { DCR } & B \\ J P & \text { PCVP }\end{array}$

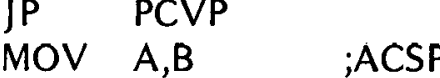

RAL

R.AR

MKV B,A ;BCSP

;POSITIVE CMD VALUL CONVLRSION

$\begin{array}{ll}\text { LXI } & H, \emptyset \\ \text { DAD } & S P\end{array}$

MOV A,B

$\begin{array}{lll}\text { CMA } & \text { BO } \\ \text { MOV } & B, A \\ \text { MOV } & \text { A, }\end{array}$

MOV A,C

MOV $C, A$

MOV A,H

CMA $A, H$

$\begin{array}{ll}\text { MOV } & H, A \\ \text { MOV } & A, L\end{array}$

$\begin{array}{ll}\text { MOV } & \text { L,A } \\ \text { LXI } & S P, 1\end{array}$ $\begin{array}{lll}\emptyset 1 A A 39 & \text { DAD } & \text { SP } \\ \emptyset 1 A B \text { D2AFF1 } & \text { JNC CNMO } \\ \emptyset 1 A E \text { CB } & \text { INX } & \text { B } \\ \emptyset 1 A F \text { F9 } & \text { CONMO: SPHL }\end{array}$

;BCSP

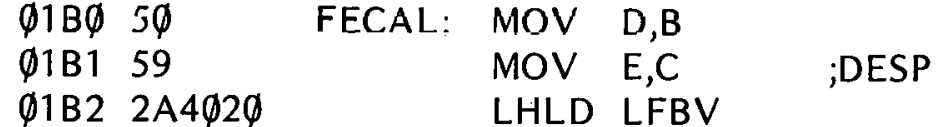

$\begin{array}{lll}\emptyset 1 B 539 & 39 & \text { DAD SP }\end{array}$

Ф1B6 D2BAØ1. JNC TWO

Q1BA EB TWO: XCHG

Ø1BB F9

Q1BC $2 A 422 \emptyset$
G1BF 39

Q1BF 39
Q1C $\mathrm{EB}$

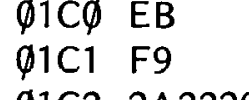

$\begin{array}{ll}\phi 1 C 2 & 2 A 222 \emptyset \\ \emptyset 1 C 5 & 39\end{array}$

91C6 D2CA 11

Ф1CA EB

$\phi 1 C B$
$\emptyset 1 C C$ $2 A 2 \emptyset 2 \emptyset$

Ø1CF 39

$\emptyset 1 D \emptyset 222 \varnothing \emptyset$

Ф1D4 $22222 \emptyset$

$\begin{array}{ll}\emptyset 1 \mathrm{D} 7 \mathrm{AA} \\ \emptyset 1 \mathrm{D} 8 & 17\end{array}$

$\begin{array}{lll}\emptyset 1 \mathrm{D} 8 & 17 \\ \emptyset 1 \mathrm{D} 9 & 3 \mathrm{~F} \\ \emptyset 1 \mathrm{DA} & 1 \mathrm{~F}\end{array}$

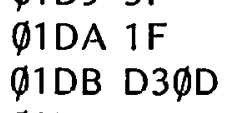

Ф1DD $7 B$

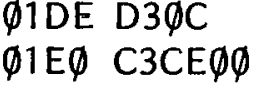

$\begin{array}{ll}\text { SPHL } & \text {;HLDE } \\ \text { SPHL } & \text {;PDE }\end{array}$

;

PHL

JNC TWOMO

TWOMO: XCHG

;HLDE
SPHL

LHLD் FEMIL

DAD SP ;HLDE

XCHG ;DEHL

SHLD FESUB ;FE OUTPUT

MOV $A, D$

RAL

RAR

$\begin{array}{ll}\text { OUT } & 13 \\ \text { MOV } & A, E\end{array}$

;OFFSET BINARY FORMAT

JMP RFBC
LHLD HFBV ; ; $\quad$ HIGE 


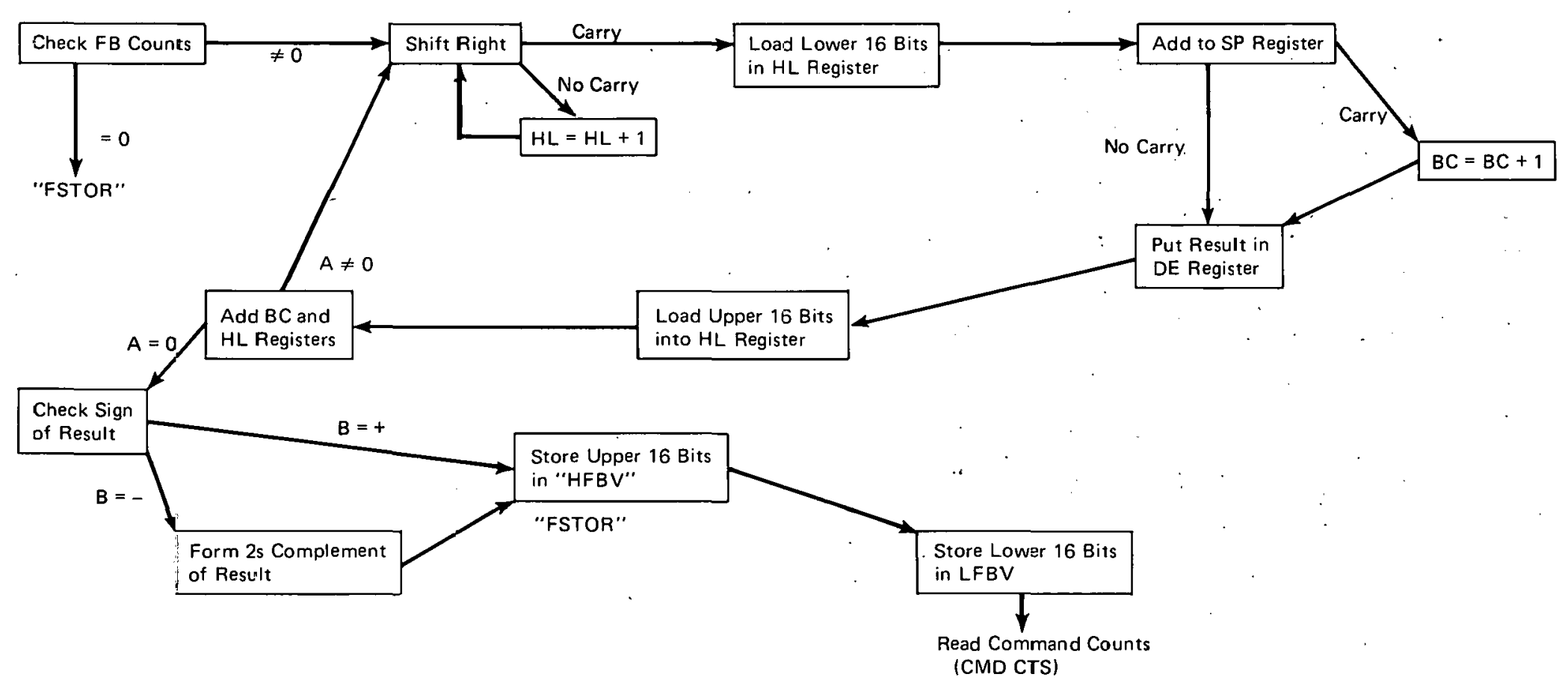

Figure B-4. FEEDBACK COUNTS CONVERSION FLOW CHART. 


\section{Algorithm Logic (subroutine 12)}

This section is used to describe some of the logic behind the form of the final control algorithm.

The up/down counters used represented +1 as 0001 and -1 as 1111 , so a direct conversion from counts to picoinches (via multiplication, addition, or whatever) was not easily done. It was decided to treat all counts in the positive form so that an absolute-value conversion could be formed. This action reduced the program complexity and storage required. Given this assumption, it is then necessary to keep track of the actual sign for later adjustment of the converted results. Addition of appropriate constants based on a carryout following a shifting operation was chosen over other multiplication techniques on the basis of speed.

Since 2s-complement arithmetic was used to form the quantity - FE = FB CTS - CMD CTS, it was necessary to modify the conversion results of the CMD CTS to obtain the desired subtraction. If the CMD counter contents were negative, then the contents were $2 \mathrm{~s}$ complemented, converted, and added to the FB conversion results since the 2 s-complement form was needed for the -FE calculation. However, if the CMD counter contents were positive, then it was necessary to complement the results of the LIMU CIS conversion.

Similar logic was followed following the FB CTS conversion. Here, of course, it was necessary to complement the conversion results when the FB counter contents were negative. 
Table B-5

SOFTWARE DOCUMENTATION

Examples: $-F E=F B-C M D$, both conversion factors equal two.

a) For a positive number of $F B$ counts

i) Positive CMD counts

$F B=3, C M D=2$.

$\begin{array}{ccccc}\text { CTS } & 0011 & 0010 & & 0110 \\ \text { convert } & 0110 & 0100 & & 1100 \\ & & 1011 & \text { 1's comp. } & 0010 \rightarrow+2 \\ & & 1100 & 2 \text { 's comp. }\end{array}$

ii) Negative CMD counts

$\mathrm{FB}=2, \mathrm{CMD}=-1$

$\begin{array}{ccccc}\text { CTS } & 0010 & 1111 & & \\ \text { convert } & 0100 & 0000 & \text { 1's comp. } & \\ & & 0001 & \text { 2's comp. } & 0100 \\ & & 1010 & \text { convert } & 0010 \\ & & 0010 & \text { clear sign bit } & \overline{0110} \rightarrow+6\end{array}$

Note that in this instance it is necessary to clear the sign bit before proceeding.

b) For a negative number of FB counts

i) Positive $C M D$ counts

$\mathrm{FB}=-1, \mathrm{CMD}=+2$

$\begin{array}{ccccc}\text { CTS } & 1111 & 0010 & & \\ \text { 2's comp. } & 0001 & 0100 . & \text { convert } & 1100 \\ \text { convert } & 1010 & 1011 & 1 \text { 's comp. } & 1110 \\ \text { clear sign } & 0010 & 1100 & 2 \text { 's comp. } & \frac{1010}{2} \rightarrow-6 \\ \text { 2's cump. } & 1110 & & & 0101 \\ & & & & 0110\end{array}$

$$
\begin{array}{r}
-1(2)-2(2)=? \\
-2-4=-6
\end{array}
$$

$$
\begin{array}{r}
2(2)-(-1)(2)=? \\
4-(-2)=6
\end{array}
$$

ii) Negative CMD counts

$$
\mathrm{FB}=-2, \mathrm{CMD}=-2
$$

\begin{tabular}{cc} 
CTS & 1110 \\
2's comp. & 0010 \\
convert & 1100 \\
clear sign & 0100 \\
2's comp. & 1100 \\
\hline
\end{tabular}

1110
0010
1100
0100

$$
-2(2)-(-2)(2)=?
$$$$
-4+4=0
$$

$\begin{array}{ll}\text { 2's comp. } & 1100 \\ \text { convert } & 0100 \\ \text { clear sign } & \overline{0000} \rightarrow 0\end{array}$


SN7400N

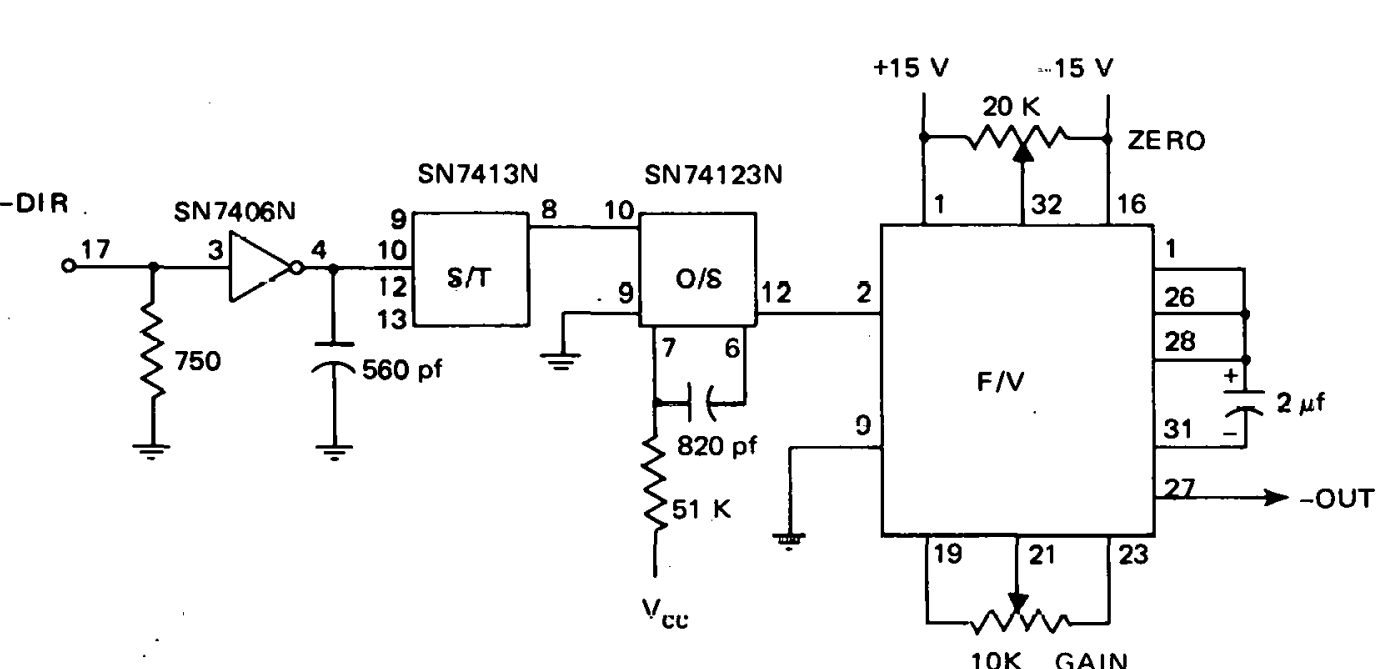

$$
\text { -OUT } \underbrace{18.2 \mathrm{~K}}_{18.2 \mathrm{~K}}
$$
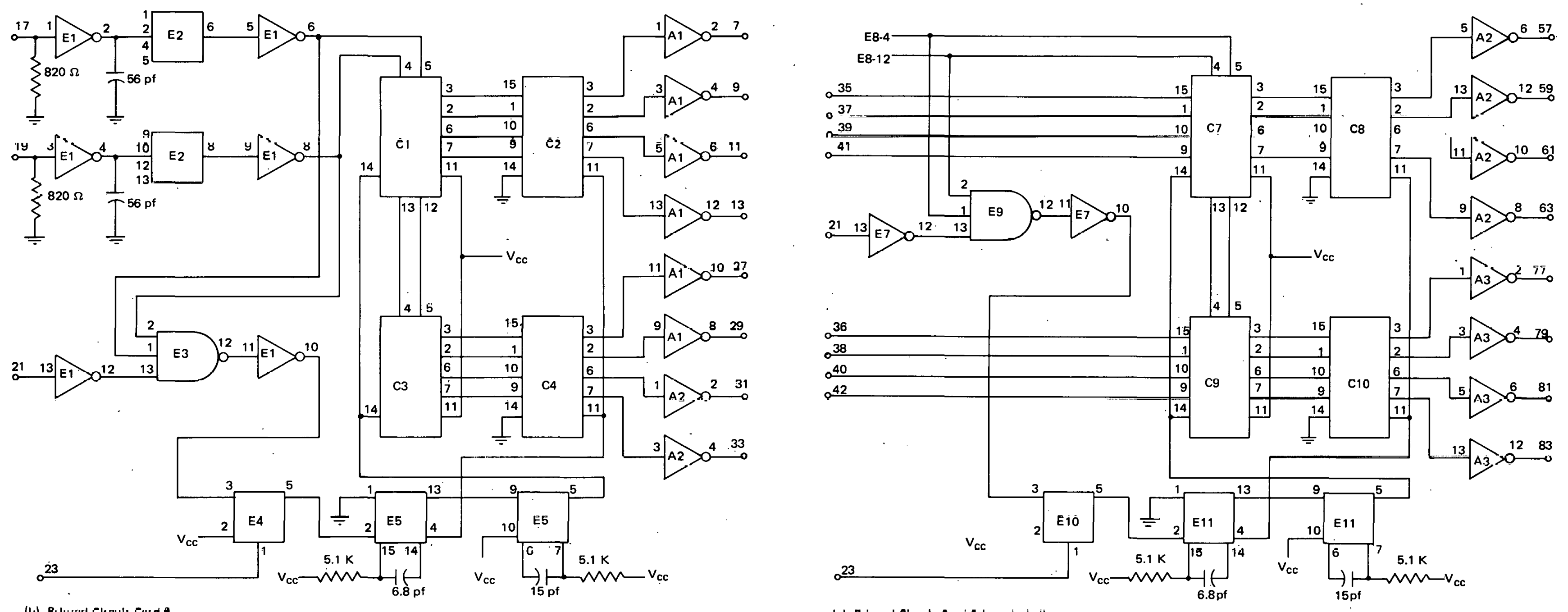

(b) Pillined Elrcult Eard $\theta$.

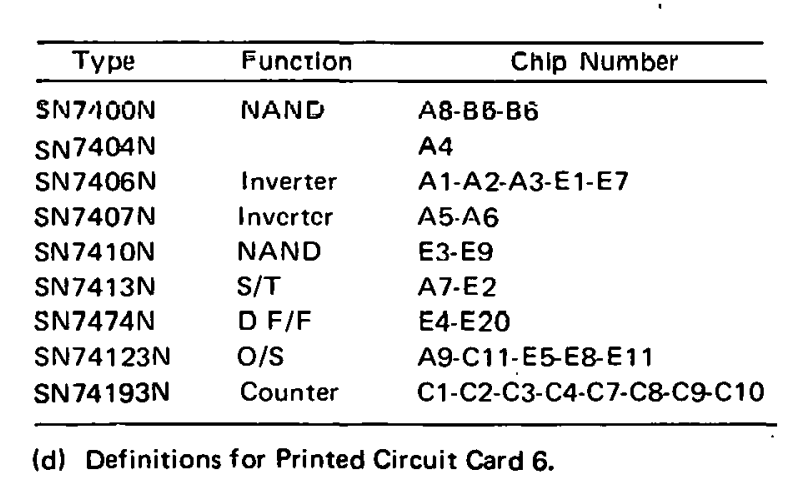




\section{Distribution}

Energy Research and Development Administration - Oak Ridge

Hickman, H. D.

Leed, R. E.

Zachry, D. S., Jr

\section{Lawrence Livermore Laboratory}

Bryan, J. B.

Chapman, W. H.

Jepson, J. O.

Nelson, W. E.

\section{Los Alamos Scientific Laboratory}

Hoyt, H. C.

\section{Oak Ridge Gaseous Diffusion Plant}

Stief, S. S.

Wilcox, W. J., Jr

\section{Oak Ridge National Laboratory}

Weir, J. R., Jr

\section{Oak Ridge Y-12 Plant}

Alvey, H. E.

Anderson, P. J.

Armstrong, R. C.

Barkman. W. E. (25)

Bookhart, T. W.

Burditt, R. B.

Butturini, W. G.

Dawson, D. O.

Douglass, S. S.

Duggan, H. G.

Foulk, D. L.

Fraser, R. J.

Gerth, H. L.

Gritzner, V. B.

Hensley, C. E.

Hewgley, R. E., Jr

Hurst, J. S.

Jones, F.W.

Kahl, K. G.

Keith, A.

Kite, H. T. (20)
Marrow, G. B.

Martin, W. R./Googin, J. M.

Mason, D. L./Schreyer, J. M.

Mills, J. M., Jr

Murphy, S. M., Jr

Oliphant, G.W.

Pearson, K. O.

Perry, A. E.

Phillips, L. R.

Ruse, R. P.

Smith, H. F., Jr

Smith, R. D.

Steger, P. J,

Stoner, H. H.

Tewes, W. E.

Thompson, C. H.

Tilson, F. V.

Whitson, W. K.

Whitton, L. G., Jr

Wright, C. C.

$Y-12$ Central Files (master copy)

Y-12 Central Files (route copy)

$Y-12$ Central Files (Y-12RC)

$Y-12$ Central Files (5)

Paducah Gaseous Diffusion Plant

Millican, R. M.

Union Carbide Corporation - New York

Chambers, W. E.

Winters, Charles

\section{University of Tennessee-College} of Engineering

Stansbury, E. E.

In addition, this report is distributed in accordance with the category UC-38, Engineering and Equipment, as given in the USERDA Standard Distribution Lists for Unclassified Scientific and Technical Reports, TID-4500. 